\title{
TroyAcademy
}

International Journal of Social Sciences

\section{Yetenek Yönetiminin İnovasyona Etkisi: İstanbul İlinde Endüstriyel Mutfak Sektöründe Bir Uygulama}

\author{
Araştırma Makalesi/Research Article
}

\section{Necmiye Tülin İRGE* Yüksel YALÇIN** Yaşar UYSAL ${ }^{* * * *}$}

\section{ÖZET}

Bu çalışmada, yetenek faktörü ile inovasyon ilişkisi incelenerek, işletmelerde yeteneğin inovasyon süreçlerinde daha güçlü bir geliştirme aracı olarak kullanılmasına katkı sağlaması amaçlanmıştır. Kavramsal olarak, 1980'li yıllarda kullanılmaya başlamış olan inovasyonun, 2000'li yıllardan itibaren işletmelerin performans yönetimlerinde etkin bir yönetim aracı olduğu gözlemlenmektedir. Son yıllarda ürün ve hizmet alanındaki yeniliklerin pazarda sürükleyici rol üstlenmesinin, inovasyonu stratejik açıdan işletmelerin var olma sebebine dönüştürdüğü görülmektedir. İşletmelerin stratejik rekabeti açısından en değerli kaynaklarından biri olan insan kaynağının daha verimli yönetilmesi gerekliliğinden hareketle, bu kaynağın çekirdek yapısını oluşturan yetenek, saha araştırmasının konularından biri olarak seçilmiştir. Çalışmada tercih edilen endüstriyel mutfak sektörü ise günümüzde yiyecek, içecek ve ikram sektörünün sürekli gelişmesiyle, bu ürünlerde çok fonksiyonluluk, enerji tasarrufu, çevre hassasiyeti, ergonomik üstünlükler ve servis dostu gibi niteliklerle inovasyonun stratejik üstünlük haline gelmesi öngörüldüğünden seçilmiştir. Araştırma 2019 yılının Eylül ve Aralık ayları arasında, kolayda örnekleme yöntemi ile, İstanbul ili Avrupa yakasında endüstriyel mutfak ekipmanları sektöründe faaliyet gösteren bir firmada çalışan 218 kişi üzerinde uygulanmıştır. Toplanan veriler SPSS 22 programında ölçek geçerlilik ve doğrulayıcı faktör analizlerine tabi tutulmuştur. Yapılan basit ve çoklu regresyon analizi sonuçlarına göre; yetenek yönetimi değişkeninin inovasyon değişkenini anlamlı bir şekilde etkilediği ortaya konmuştur.

\section{Anahtar Kelimeler: Yetenek, Yetenek Yönetimi, İnovasyon, Yenilikçilik, Endüstriyel Mutfak}

\section{Impact of Talent Management on Innovation: An Application in İstanbul Culinary Industry}

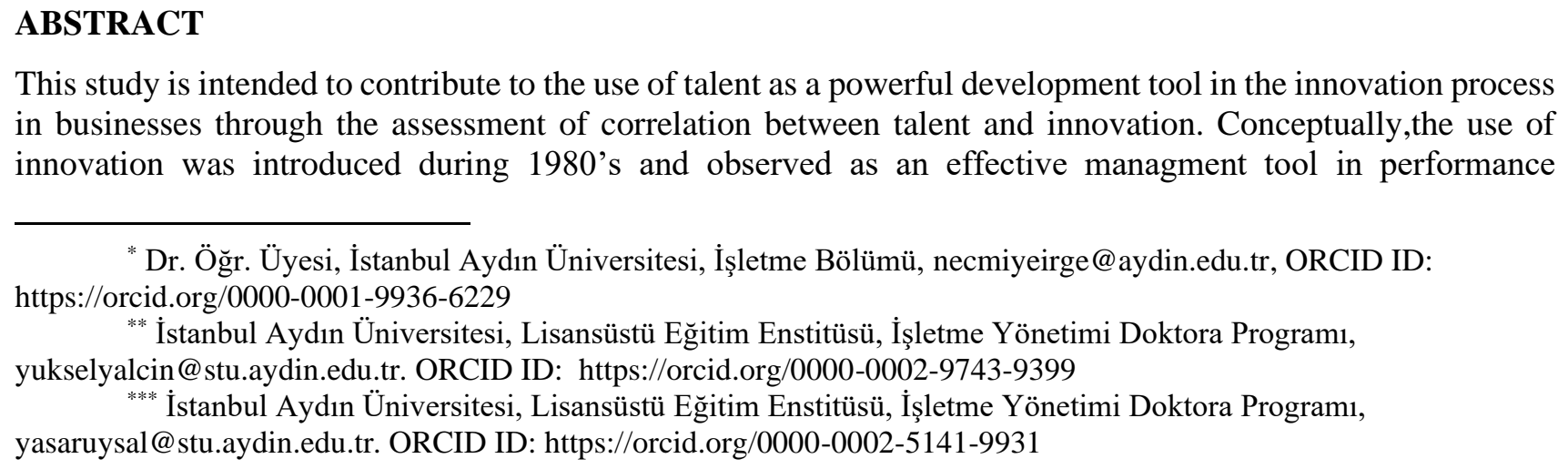

This study is intended to contribute to the use of talent as a powerful development tool in the innovation process in businesses through the assessment of correlation between talent and innovation. Conceptually, the use of innovation was introduced during 1980's and observed as an effective managment tool in performance

\footnotetext{
* Dr. Öğr. Üyesi, İstanbul Aydın Üniversitesi, İşletme Bölümü, necmiyeirge @ aydin.edu.tr, ORCID ID: https://orcid.org/0000-0001-9936-6229

** İstanbul Aydın Üniversitesi, Lisansüstü Eğitim Enstitüsü, İşletme Yönetimi Doktora Programı, yukselyalcin@stu.aydin.edu.tr. ORCID ID: https://orcid.org/0000-0002-9743-9399

*** İstanbul Aydın Üniversitesi, Lisansüstü Eğitim Enstitüsü, İşletme Yönetimi Doktora Programı, yasaruysal@stu.aydin.edu.tr. ORCID ID: https://orcid.org/0000-0002-5141-9931
} 
managment since 2000's. In recent years, innovation in products and services have assumed a gripping role in the market and has been transformed to be reason of existence for businesses in strategic contemplation. The necessity to efficiently manage human resources in terms of the strategic competition of businesses ,talent that the core structure of resource, is selected as a topic of this field research.Industrial Kitchen sector is preferred with the anticipation that innovation is turn out to be a strategic supremacy with characteristics such a multifunctionality,energy saving,environmental sensitivity,ergonomic distinction and service friendliness. The study was conducted at a company in İstanbul from September to December 2019 by means of the convience sampling method on 218 individuals employees. The collected data were investigated through index reliability and confirmatory factor analysis in the software SPSS 22. Based upon the results of single and multiple regression analysis,the variable of talent managment is demonstrated to significant affect on the variable of innovation.

Keywords: Talent, Talent Management, Innovation, Industrial Kitchen

\section{GİRIS}

Endüstriyel ekosistemin gelişimi örgütsel disiplinleri de etkilemiştir. Bu disiplinlerde birçok süreç değişime uğrasa da, tarihsel akışta insan hep merkezde kalmıştır. Başarılı işletmelerin iş yaşam öykülerinde, insan kaynakları departmanlarının iç süreçleri de nitelik açısından önemli değişimler geçirmiştir. Rekabetçi küresel pazar, işletmelerde insan kaynakları yönetimlerinde, daha fonksiyonel, esnek, eğitim tabanlı ve yenilikçi yaklaşımları gerekli kılmıştır. Bu yeni nesil kaynak yönetimlerinde, operasyonel mükemmellik için “yetenek yönetimi” öncelikli bir konuma taşınmıştır.

İşletmelerin, yönetsel süreçlerde daha verimli insan kaynakları programları için, daha nitelikli ve tecrübeli kaynak tahsisine ya da mevcut kaynakların kişisel becerilerini geliştirmeye dönük programlara yöneldiği gözlemlenmektedir. Uluslararası markalara sahip işletmeler, nitelikli insan kaynakları planlamasında eğitimi, yetenekleri geliştiren bir araç olarak görüp, iş programlarının bir parçası saymaktadırlar.

Ürün ve hizmetteki katma değeri yüksek farklılaştırma politikaları, karlılık ve rekabet üstünlüğü açısından önemli bir güce dönüşmüştür. Bu bağlamda "ticari getirisi yüksek yenilikçilik" anlamına gelen inovasyonun, sistematik ar-ge uygulamalarının bir unsuru olarak piyasada markaları sürükleyici bir güce dönüştürdüğü yönetim bilimcilerinin yaygın kanaatleri arasındadır.

$\mathrm{Bu}$ çalışma temelinde, yetenek yönetiminin, işletmelerin tüm birimlerinde inovasyon süreçlerine kazandıracağı katma değerlerle, kurumların başarısındaki rolünün daha da iyi anlaşılmasına katkı sağlayacağı düşünülmektedir. Çalışmanın sonuç kısmında, yetenek yönetiminin inovasyon süreçlerinde daha etkin bir şekilde uygulanması ve yön vermesi amacıyla öneriler de sunulmuştur.

\section{LITERATÜR TARAMASI}

Yapılan literatür taramasında yetenek yönetimi ve inovasyon kavramlarının başka değişkenlerle ilişkilerinin araştırıldığı birçok çalışmaya rastlanmıştır. $\mathrm{Bu}$ araştırmaların bazıları aşağıda ele alınmaktadir. 
Vatan'ın (2010) yaptığı araştırmada İstanbul'da beş yıldızlı konaklama işletmelerinde inovasyon eğilimleri ortaya konulmaya çalışılmıştır. Araştırma sonuçlarına göre, işletmelerin yeniliğe yönelik zorunluluklarının farkında olduğu ve yenilik ile ilgili esnek ve açık bir yönetim sergiledikleri belirlenmiştir. Turizm işletmelerinin farklılığını oluşturan temel unsurlar olan ürün ve hizmet inovasyonunun daha zor olması, işletmelerin süreç ve pazarlamaya ilişkin inovasyonu tercih etmelerine neden olmaktadır. Konaklama işletmelerinde yeni bir hizmet süreci geliştirmenin zor olması var olan hizmet ve ürünlerin farklı yönlerinin öne çıkarılarak pazarlama süreçlerinde inovasyonu etkili kılmaktadır. Bunun yanında hizmetlerin sunuluş biçimlerindeki yeniliklerinde zaman maliyeti açısından kolay olması inovasyonun bu alanda da öne çıkmasına neden olmaktadır. Araştırma sonucunda, turizm işletmelerinde temel olarak süreç ve pazarlama inovasyonunun görüldüğü tespit edilmiştir.

Özdevecioğlu ve Biçkes (2012) araştırmalarında inovasyon türleri arasında bulunan örgütsel öğrenme inovasyonu ile ürün, süreç, strateji ve pazar inovasyonu arasında aynı yönlü bir ilişki bulunduğunu belirlemişlerdir. İşletmelerde örgütsel öğrenmenin, ürün, süreç, strateji ve pazar inovasyonu tarafından olumlu bir şekilde etkilendiği, örgütsel öğrenme düzeyi yüksek olan işletmelerin inovasyona yönelik taleplerinin ve inovasyon düzeylerinin de yüksek olduğu elde edilen sonuçlar arasındadır.

Arshi (2013) çalışmasında örgütsel kültürün inovasyon ile ilişkisini araştırmıştır. Araştırma sonuçlarına göre, örgütsel kültürün geliştirilmesi için inovasyon yatırımlarının gerekli olduğu ve inovasyonun örgütsel kültürü olumlu olarak etkilediği tespit edilmiştir. Örgütsel kültürde geleceğe yönelik belirsizliklerin kabul edilmesi, risklerin tespit edilmesi ve belirlenmesi, paydaşların geri bildirim sürecine aktif katılımı, örgütsel yaratıcılığa yönelik örgüt ikliminin desteklenmesi inovasyon ile desteklendiğinde yararlı olacaktır. Bu süreçte, inovasyon çalışmalarının kurum içi sürekli eğitim, ödüllendirme ve inovasyonun gerçekleştirilmesi için gerekli bilgi altyapısının sağlanması ve dengeli bir inovasyon politikasının oluşturulmasının önemi ortaya konulmuştur.

Güner (2016) çalışmasında işgörenlerin yetenek yönetimi faktörlerinden iş tatmini ve yetkinlik algıları üzerinden olduğu belirlenmiştir. İşgörenlerin yeteneklerinin desteklenmesi ve geliştirilmesinin iş doyumu ve motivasyonunu üzerinde olumlu bir etkiye sahip olduğu, işgörenlerin içsel motivasyonlarının kurum desteği ve operasyonel uyum, yetkinlik ve kuruma güven algıları ilişkili olduğu saptanmıştır. İşgörenlerin dışsal motivasyonu ile yetenek yönetimi algıları arasındaki ilişkiler incelendiğinde sırasıyla kurum desteği ve operasyonel uyum, öz yeterlilik ve kuruma güven algılarının dışsal motivasyonlarını olumlu etkilediği tespit edilmiştir. Kadın ve erkek işgörenlere göre yetenek yönetimi algılarında farklılık belirlenmezken diğer demografik özelliklere göre yetenek yönetimi 
algıları farklılaşmaktadır. Araştırmada ayrıca, işgörenlerin işletme içinde iş pozisyonlarının kuruma güven algılarını farklılaştırdığı ancak yetenek yönetimi açısından etkili olmadığı da belirlenmiştir.

Kanap Güngör'ün (2013) yapmış olduğu çalışma ile yetenek yönetimi uygulamalarının çalışanların performansı üzerinde pozitif yönde etkisi olduğu ortaya konmuştur. Çalışanların performanslarının arttırılmasında kuruma güven algılarının oldukça önemli olduğu belirlenmiştir. Kişisel-mesleki özellikleri ve eğitim-deneyimleri ile kurumda bulunduğunu düşünen çalışanlar, işletme için daha faydalı olabilmektedirler. Kurumsal destek ve uyumun çalışan performansı ile ilişkileri incelendiğinde işletme yönetiminin çalışanların kişisel gelişimleri ile mesleki gelişimlerine destek verilmesi, hizmet içi eğitimler ile gelişimlerinin güçlendirilmesi ve maddi ödüllere yönelik algılarının çalışan performansını arttırdı̆̆ 1 belirlenmiştir.

Genel olarak güven duygusunun bireyin başta kendisini gerçekleştirmesinde, yeteneklerinin keşfinde, ikili ve toplumsal ilişkilerde, en önemlisi psikolojik faktörler içerisinde kritik bir öneme sahip olduğu görülmektedir. Günümüzde kurumsal işletmelerde ve örgüt yönetimlerindeki başta yönetici ve lider pozisyonundaki çalışanlara güven olgusunun, bireysel yeteneği güçlendiren önemli bir unsur olduğu görüşü önem kazanmıştır. Yöneticiye güven ve kaliteli lider-üye etkileşimi çalışanların motivasyonlarını artırmaktadır (İrge, 2016:54).

Altınöz (2018) araştırmasında 4 yıldızlı otellerdeki yetenek yönetimi uygulamalarının 5 yıldızlı otellere göre daha etkili olduğu belirlenmiştir. Araştırma sonuçlarına göre 4 yıldızlı otel yöneticilerinin işgörenlerini destekleme düzeylerinin daha yükssek olduğu, karar alma süreçlerinde çalışan katılımına önem verdikleri ve işgörenleri motive etme düzeylerinin yüksek olduğu görülmektedir. Buna karş1lık turizm sektöründe yetenekli personelin sahip oldukları özellikler ve beklentileri nedeniyle 5 yıldızlı işletmeleri tercih ettikleri, 5 yıldızlı otellerin güçlü marka imajlarını yetenekli personeli çekme konusunda avantaj sağladığı belirlenmiștir. 4 yıldızlı firmaların bünyelerinde düzenledikleri eğitimlerle işgörenlerin gelişimine önem verdikleri ve iç kaynaklara başvurulmasıyla yetenekli işgörenleri iç bünyelerinden tedarik etmeyi planladıkları düşünülmektedir.

$\mathrm{Bu}$ çalışma için yapılan literatür taramasında yetenek yönetiminin inovasyona etkisini araştıran ve her iki değişkeni bir arada inceleyen bir çalışmaya rastlanılmamıştır. Araştırmalarda da yer aldığı üzere, çalışanları daha başarılı kılmak açısından "Yetenek Yönetimi”nin, sürdürülebilir gelişim ve rekabet için “İnovasyon Yönetimi”nin işletmeler için çok önemli iş modelleri haline geldiği görülmektedir.

\subsection{Yetenek Kavramı ve Yetenek Yönetimi}

Türk Dil Kurumu (TDK) Genel Türkçe Sözlüğü’nde yetenek; “bir kimsenin bir şeyi anlama veya yapabilme niteliği, kabiliyet, istidat”; "bir duruma uyma konusunda organizmada bulunan ve doğuştan 
gelen güç, kapasite”; “kişinin kalıtıma dayanan ve öğrenmesini çerçeveleyen sınır” ve "dışarıdan gelen etkiyi alabilme gücü” şeklinde ifade edilmektedir. (http://www.tdkterim.gov.tr). Başka bir bakış açısıyla yetenek, bir kişinin tekrarlanan duygu, düşünce veya davranış kalıplarını verimli bir şekilde kullanabilmesi becerisidir. Bu tanımla birlikte, empati, incelik, tez canlılık, odaklanma, rekabetçilik, stratejik düşünme gibi beşeri özellikler de bir yetenektir (Buckingham ve Vosburgh, 2001: 21).

Yetenek, "bir kimsenin bir şeyi anlayarak yapabilme niteliği, birden fazla konuya da spesifik alanda sahip olunan içsel doğal kabiliyet, eğitim ve deneyimle, ileri düzeyde yeterliğe ulaşabilen, özel bir alandaki üst düzey kabiliyet" olarak tanımlanmaktadır (Akar, 2015: 17). Bu tanımlar, yeteneğin, bireyin doğuşuyla başlayan beşeri niteliklerini özel alanlarda güçlü bir şekilde gösterebilme kapasitesi ve yatkınlığı olarak tanımlanabilir. Yetenek ayrıca, sosyo-psikolojik bakımdan bilim insanları tarafından inceleme alanındadır. Kurumsal yapılarda yetenek, organizasyonların stratejik açıdan daha güçlü avantaj elde edebilmeleri için, insan kaynaklarını daha verimli kullanmak ve yetenek faktörünü kurum içi faydaya dönüştürerek bir rekabet avantajı elde etmeye dönük çabalar olarak değerlendirilebilir (Ağraş ve Kılınç, 2014: 3).

Bir kuruluşun iç yetenek potansiyelinden tam olarak yararlanabilmesi için, kurum içerisinde, performansı farklı ve güçlü şekilde etkileyebilecek potansiyellerin tanımlanmaları gerekir. Böylelikle, yetenek esaslı kaynaklar bu pozisyonlar için hazır hale geçebilir. Bu bağlamda, asıl önemli olan bu kritik pozisyonları doldurmak için yüksek potansiyelli ve yüksek performanslı çalışanlardan oluşan yetenek havuzları oluşturmaktır. Dolayısıyla, bu yetenek havuzlarından yararlanma potansiyelini en üst düzeye çıkarmak için, kurum içinde daha nitelikli insan kaynakları mimarisi, kaynak ihtiyaçlarına verimli bir altyapı oluşturabilir (Collings ve Mellahi, 2009: 27).

İnsan kaynaklarında yetenek ve yetenek yönetimi, 2000'li yıllara yaklaştığımız dönemlerde “çalışanların yetkinliği” konusu ile gündeme gelmiştir. "Yetkinlik, büyük ölçüde başarı ile ilgili psikolojik ya da davranışsal nitelikler olarak değerlendirilmekte olup, bireyin herhangi bir işteki veya durumdaki etkili veya üstün sonuca ulaştıran temel özelliği şeklinde tanımlamıştır” (Budak ve Akyol, 2013: 157). Yetenek yönetiminin, örgütsel bağlılık ve proje yönetimi performansı arasında pozitif bir ilişki olduğu yapılan araştırmalar arasındadır. Bu konuda Mahdiyeh ve arkadaşlarının SMART PLS yazılımı kullanarak yaptıkları çalışmada, proje tabanlı bir organizasyonda yeteneklerin, projelerin durumu üzerindeki stratejik yönetiminin rolü bireysel yönlere, memnuniyet, motivasyon ve örgütsel bağlılığa dayalı olarak analiz edilmiş, sonuç olarak, proje tabanlı organizasyonlarda stratejik yetenek yönetimi ile proje başarısı arasında anlamlı bir ilişki olduğunu göstermişlerdir. "Stratejik yetenek yönetimi ile örgütsel bağlılık arasında pozitif ve anlamlı bir ilişki vardır ve bu da stratejik yetenek yönetiminin varlığını gösterir” (Mahdiyeh vd.,2018: 9). 
Ticari firmalar, kararlı çalışanları elde tutmaya yardımcı olacak çeşitli politikalar, stratejiler ve eylemler üreterek performansı artırma eğilimindedir. Yetenek yönetimi, organizasyonel başarının önemli bir belirleyicisidir (Oludayo vd., 2018: 1).

Yetenek yönetimi akademik araştırmalarda kavramsal olarak incelendiğinde; ileri yeteneklilerin seçimi, çalışanlara eğitim ve geliştirme alanları sağlanması, yetenekli çalışanlara koçluk, yetenekli çalışanların değerlendirilmesi ve bu çalışanları elde tutma stratejilerini içerdiği görülür. Yetenekli çalışanların elde tutulma sürecine ilişkin olarak çalışanların özendirilmesi, motivasyon araçlarının kullanılması, yetenekli çalışanlara kapsamlı destekler sağlanması, uygun çalışma koşullarının oluşturulması, ve kişiye uygun işler sağlanması, ana çıktılar arasındadır. Bu alt çıktılara yönelik en çok yorum ise motivasyon programlarına odaklanmadır (Gündüzalp, Boydak, 2019: 10).

Yetenek yönetimi, herhangi bir özel sektör firmasında uygulanmadan önce, toplumun kültürü ve değerleri ile ilgili zorluklar dikkate alınmalıdır. Bunun yanısıra yetenek yönetiminin doğasının ve kilit paydaşların rolünün de göz önünde bulundurulması gerekmektedir (Foteini ve Kravariti, 2020: 86).

Demografik özellikler, teknoloji ve küreselleşmeye paralel olarak 4. Sanayi Devrimi, iş yapma biçimini çalışanlarla birlikte muazzam çıkarımlarla dönüştürdü. İnsan kaynaklarının yetenek yönetimini yeniden keşfetmesi ve yeniden yapılandırması, firmalara benzersiz fırsatlar yanında bir takım zorluklar da getirdi. Klasik İK modellerini benimseyen şirketlerin, iş modelleri bu hızla değişmeye devam ettikçe bunların kısa ömürlü olması da muhtemeldir. Akademisyenler, yeteneklerin elde edilmesini ve performansını etkileyen eğilimleri belirleyerek, öngörerek ve araştırarak profesyonel yetenek yönetimi uygulamalarını destekleyebilirler (Claus, 2019: 213)

Yetenek Yönetiminin sistematik alt süreçleriyle birlikte ele alınması nedeniyle kapsamlı olmasından hareketle, sürecin başarısı açısından kurum içinde ilk önce yetenek yönetimi anlayışının içselleştirilmesi gerekmektedir. Yönetici ve çalışanlar boyutunda bu sürecin benimsenmemesi durumu, rutin verimi de başarısızlığa uğratabilir (Öner, 2014: 31).

\section{2. İnovasyon}

İnovasyon; farklı, değişik ve yenilikçi fikirler geliştirerek bunların iş yaşamında uygulanması olarak ifade edilebilir. İnovasyon, teorik kavram, teknik yenilik ve ticari uygulamaların bir toplamı olarak değerlendirilmektedir. Yaygın kanaatle ise, yeni ve yenilikçi düşüncelerin, uygulanabilir bilginin ekonomik ve toplumsal faydaya dönüştürülmesidir (Savaşçı, 2004: 517).

İnovasyonun tanımı incelendiğinde icat (buluş) ile önemli farklılıklara sahip olduğu görülmektedir. İşletmeler açısından üretim, dağıtım ve pazarlama alanında yeni buluşların yararı tartışılmazdır. Ancak, buluş, iş anlayışı açısından yeni bir düşüncenin geliştirilmesi ve bulunması iken, inovasyon bu 
düşüncenin ticari bir yararının elde edilmesi sürecidir. Görüldüğü gibi buluş ile inovasyon arasında önemli bir ilişki bulunmasına karşılık farklılıklar bulunmaktadır (Fagerberg, 2003: 3). Bu anlamda icat (buluş) ile inovasyon arasındaki farkı ortaya koyabilmek oldukça basittir. İşletmelerin üretimde yeni bir yöntem ya da ürün geliştirmesi ile yaşanan teknik değişim icat olarak tanımlanabilir. Buluşun bir farklı1ık oluşturacak şekilde ticari hayatta kullanılması ve farklı bir bakış açısı ile uygulamaya konulması ise icadın yeniliğe dönüşmesini ifade etmektedir.

İnovasyon kavramsal tanımının yanında uygulama biçimi itibarıyla, belli aşamalardan oluşan bir süreçtir. Öncelikle inovasyon fikrinin üretilmesi ve seçiminde, fikre konu olan içeriğin iç ve diş araştırmalarla başlayan yapısı tanımlanır. İnovasyona konu olan fikir, tedarik zinciri süreçlerinden, teknolojik kaynaklı konulardan veya pazarın taleplerinden doğabilir. Fikre konu olan çalışmanın teknoloji pazarla ilgili fizibilitesinin yapılması ve muhtemel ekonomik başarılarının değerlendirilmesi önemlidir. Neticede, ürün halini alan bu fikir ticarileştirildiğinde inovasyon gerçekleştirilmiş olmaktadir. (Sattler, 2011, s.12).

İnovasyonu, sadece ürün gelişimi olarak görmemek gerekir. İşletme genelindeki tüm süreçlerde yenilik; örgütsel tasarım, süreç tasarımı, teknolojik yenilikler, ücret sistemleri, bilgi ve veri tabanı yönetimi, kaynak performansları yönetimi, ürün geliştirme, pazar geliştirme gibi ilerlemeyi içerir. Büyük ölçekli başarılı kurumsal firmalar inovasyonu tüm süreçlerinde uygulama eğilimindedir. İşletmeler yeniliklere, daha yüksek performans ve daha fazla verim için dikkatle takip edilecek bir süreç ve faaliyetler dizini olarak yaklaşmaktadır. İnovasyon ve stratejik değişim konusunda başarılı şirketler, ürün ve süreç inovasyonuna paralel şekilde kültürel inovasyonu da takip etmektedir. İnovasyonun rekabetçi ve finansal faydalarının yanı sıra, diğer stratejik avantajları, örgütün stratejik vizyonuna kazanımları, verimliliği sürdürülebilir kılması ve yetenekleri geliştirmesi gibi katkıları çok önemlidir (Mische, 2001:129).

İnovasyon, bilim insanları ve araştırmacılar tarafından değişik perspektiflerden incelenmiş, araştırılmış ve farklı bakış açılarıyla tanımlamıştır. Drucker’a (2003) göre inovasyon; girişimciliğin bir aracıdır ve daha yüksek seviyede verim için yeni fırsatlar ve kapasite oluşturan kaynakların etkin bir şekilde kullanılmasını sağlayan bir yönetim aracıdır. Porter inovasyonun küresel pazarda rekabet üstünlüğü oluşturan, yeni teknolojileri ve yenilikçi iş yapma metotlarını kapsadığını ifade etmiştir. Rogers (1995), inovasyonu yeni olarak kabul edilen bir düşünce veya eylem yöntemi olarak ifade etmektedir. Trott (1998) inovasyonu, yönetimin bir fonksiyonu olarak ele almıştır. Damanpour (1991) ise inovasyonu; düşünce oluşturma, teknoloji geliştirme, iyileştirilmiş bir ürünün ya da üretim süreçlerinin, pazarlama, satış ve sonrasındaki müşteri memnuniyeti dahil tüm faaliyetlerdeki yenilikçi yaklaşım olarak değerlendirmiştir (Ecevit, 2010:119). 
Stratejik inovasyon, işletmelerde bilgi akış1, iletişim teknolojileri, eğitim süreçleri, müşteri ve tedarikçiler, insan kaynakları, finansal kaynaklar ve örgüt yapısının yanında, yönetsel kararlar ve bütünleşik süreçlerde değişimi işaret etmektedir. İnovasyonun kurumsal kültür haline gelmesi, için tüm fonksiyonlar tarafından desteklenmesi, karar destek süreçlerinde inovatif uygulamalara yer verilmesinde tepe yönetimin güçlü desteği ve teşvik etmesi ise son derece önemlidir. Kapsam, süreç ve bağlam olmak üzere üç temel unsuru bulunan stratejik inovasyonun, rekabet süreçlerinde stratejik yol haritasının belirlenmesi ve doğru pozisyon almaları önem arz etmektedir. İş süreçlerindeki yenilikçi uygulamalar aynı zamanda rakipler karşısında işletmeyi daha güçlü kılan, finansal başarı, yüksek hissedar kazancı ve kar elde edilerek rekabet avantajları sağlayacaktır (Hancığlu, Yeşilaydın:120,121).

Günümüz iş dünyasında inovasyon işletmelere önemli yararlar sağlamaktadır. İnovasyonun stratejik bir yönetim aracı olarak kullanılması, öncelikle üretim, dağıtım, tutundurma ve pazarlama gibi faaliyetlerin yeniden kurgulanmasını ve süreklilik sağlayacak şekilde ele alınmasını zorunlu kılmıştır. Üretim ve dağıtımdaki yeniliklerin işletme performansına olan etkisi maliyetlerin azalmasına ve kaynakların optimum kullanılmasına olanak sağlar. Bu sürecin en temel özelliği yeniliğin yatırıma dönüştürülmesi ve işletme karlılığı üzerindeki etkisinin olumlu olmasıdır (www.innovatıon.net, 2020). İnovasyon uygulamalarının temel özelliği işletmelere katma değer oluşturmasıdır. Günümüzde rekabet avantajı sağlayan inovasyon işletmelerin karlılığında önemli bir etkiye sahiptir. Üretim süreçlerinin kısalması, etkinliği ve verimliliği inovasyon ile sağlanmakta, işletmelerin yeni pazarlara sürdürülebilir rekabet ile girmesi inovasyon ile mümkün olabilmektedir. Dolayısıyla, yönetim performansı ve inovasyon arasında dinamik bir ilişkinin varlığından bahsetmek mümkündür. İnovatif bakış açısı ve süreç modelleme ile işletme performansında daha verimli çıktılar beklemek anlamlıdır. Bu kaynakların bir kısmının tekrar inovasyon sürecine aktarılması halinde, bu döngü sürdürülebilir bir yapıda seyredecektir (Tokmak, 2008: 109-110).

İşletme yöneticilerin inovasyona yönelik tutumları yönetim süreçlerini etkilemektedir. İşletmelerde inovasyon sürecinin sürdürülmesi yöneticilerin yeniliği kabullenmeleri, ticari açından değerlendirilmesi ve risk almasına göre belirlenmektedir. Kuşkusuz her inovasyon başarılı olmamaktadır. Bununla birlikte inovasyona yönelik yaklaşımların esnek olması işletmenin inovasyon yeteneğini arttırmakta ve performansına katkı sunmaktadır. İnovasyon performansı; yeni ürünlerin, süreçlerin ve fikirlerin işletmeye sağladığı yüksek katma değer veya yüksek miktardaki ticari avantaj olarak ifade edilmektedir (Ertuğ, 2015: 149). 
Günümüz iş dünyasında maliyet unsuru tek bir faktör olarak rekabet stratejisini belirlememektedir. Müşteri beklentilerini karşılayan hatta aşan ürün ve hizmet kalitesi diğer işletmelerden farklılaşmanın ve rekabetin önemli bir belirleyicisi olarak kabul edilmektedir. Dolayısıyla, inovasyon işletmelerin sürdürülebilir rekabet avantajını korumak ve gelişebilmek için önem vermesi gereken bir zorunluluktur. Küresel ekonomide inovasyona önem veren işletmeler, inovasyon politikalarını bu anlayış ile düzenlemektedir (Elçi, 2006: 27-28).

Örgütsel öğrenmenin en önemli fonksiyonu, öğrenmenin işletmenin bütün kaynaklarının en etkin şekilde kullanabilmesini sağlamaktır. Örgütsel öğrenmenin yeniden düzenlenmesi ve çağdaş bir yaklaşım ile yürütülmesi süreçlerin sürekli iyileştirilmesini sağlamaktadır (Hamel ve Prahalad, 1990). Küresel piyasalarda teknolojik yenliklerin kabul edilmesi ve işletme açısından ticari bir ürün olarak kullanılabilmesi inovasyon performansını oluşturmaktadır. İnovasyon performansı, bilgi ekonomisinin temel özelliği olan bilginin koordine edilmesi, paylaşılması ve yeni bilgilere ulaşılması için geliştirilmesi tüm yönetsel fonksiyonlar ile doğrudan ilişkilidir (Günday vd., 2011). Örgütsel öğrenme, inovasyon uygulamalarının kalitesini arttırırken bir yönü ile rekabet stratejinin esnekliğini ve etkinliğine de katkıda bulunmaktadır (Yam vd., 2011).

Kaynak tahsis yeteneği ise işletmenin en önemli kaynağı olan insan kaynağının ve sermaye birikiminin inovasyon süreçlerinin nasıl etkinleştirileceğini kapsamaktadır. Her işletmenin inovasyon politikasına uygun olarak kaynak tahsis yeteneğine yönelik farklı stratejiler uygulanmaktadır. Klingebiel ve Rammer (2014) kaynak istihdam stratejilerinin farklı seçeneklerden işletmenin rekabet avantajına en etkin katkıyı yapan alternatiflerin belirlenmesi ve inovasyon performansı üzerine çalışmalar yapmışlardır. Araştırmacılar, örgütlerin inovasyon beklentilerinde, kaynak tahsisinin önemli olduğunu, başarılı tercihlerin (tahsislerin) inovasyon performansını olumlu yönde etkilediğini belirtmişlerdir. Özellikle yenilikçi ürünlerin geliştirilmesinde bu uygulama verimli bir strateji olarak görülmektedir. Buna göre, kaynak tahsis yeteneğinin temel belirleyicileri, işletmenin sahip olduğu insan kaynağının geliştirilmesi, planlı ve sistemli çalışmalar bütünü ile fonksiyonel bölümlerde çalışacak personelin seçiminde dikkatli davranılmasıdır. Bu insan kaynakları politikalarına ek olarak inovasyon uygulamalarının sürdürülebilmesi için yeterli sermayenin aktarılması da oldukça önemlidir (Yam vd., 2011).

Yapılan literatür taramalarında işletmeler açısından sürdürülebilir rekabet ve gelişim için inovasyonun hayati önem taşıdığ 1 , başarılı bir inovasyon süreci için daha nitelikli insan kaynağı gerekliliğinin vurgulandığı görülmektedir. Bu çalışmada, iş süreçlerinde başarılı bir şekilde yönetilmesi gereken iki önemli kavram olan yetenek yönetimi ve inovasyon ilişsisi incelenmiş ve yetenek yönetiminin 
inovasyona etkisi araştırılmıştır. Bu kapsamda ortaya konan araştırma modeli ve hipotezler aşağıda sıralanmıştır.

\section{MATERYAL VE YÖNTEM}

Araştırmanın evrenini İstanbul ili Avrupa yakasında endüstriyel mutfak ekipmanları sektöründe faaliyet gösteren bir firmada çalışan 520 kişi oluşturmaktadır. Örneklemi oluşturan çalışan sayısı aşağıdaki formül ile hesaplanabilmektedir. Belirlenen evrenden örneklem hacminin hesaplanması için kullanılan formül aşağıdaki gibidir (Büyüköztürk vd., 2018).

$\mathrm{n}=\frac{\mathrm{Nt} \mathrm{t}^{2} \mathrm{pq}}{\mathrm{d}^{2}(\mathrm{~N}-1)+\mathrm{t}^{2} \mathrm{pq}}$

n= Örneklem büyüklüğü, N= Anakütle (evren) (210), p= Olayın gerçekleşme olasılığ $1(0,5), q=$ Olayın gerçekleşmeme olasılı̆̆ $1(0,5), \mathrm{t}=\mathrm{t}$ test düzeyi $(1,96), \mathrm{d}=$ Hata payı $(\% 5)$.

\%5 hata payı ile ana kütleyi (evreni) temsil edecek örneklem büyüklüğünün minimum 221 çalışan olması gerektiği hesaplanmıştır. 2019 yılının Eylül-Aralık ayları arasında, kolayda örneklem yöntemi ile anketler bu firmanın çalışanlarına elden dağıtılarak ve dijital ortamda paylaşılarak ulaşılmıştır. 221 çalışandan geri dönüş alınmıştır. Ancak 4 anket eksik ve/ya hatalı olduklarından çıkarılarak toplam 218 anket değerlendirilmeye alınmıştır.

Toplanan verilerle yetenek yönetiminin inovasyona etkisi belirlenmek amaçlanmıştır. Araştırma aşağıda tasarlanan modele göre şekillenmiştir ve yazılan hipotezler ispat edilmeye çalışılmıştır.

\section{Şekil 1. Araştırmanın Modeli}

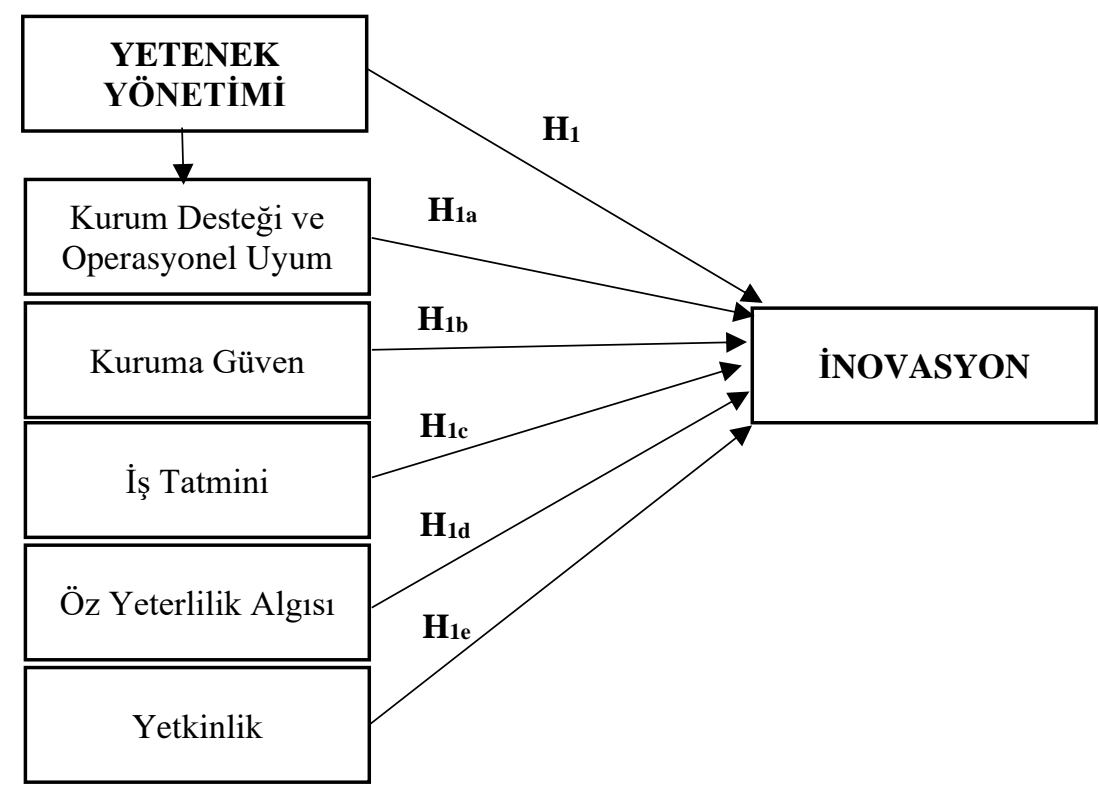

Çalışmada, örneklemden verilerin toplanmasında "survey modeli (saha taraması)" kullanılmıştır. Saha taramasında katılımcıların görüşlerinin yazılı şekilde alındığı anket tekniği tercih edilmiştir. 
Çalışmadaki anket, geniş bir literatür taraması neticesinde geçerlilikleri ve güvenilirlikleri daha önce yapılan çalışmalarda onaylanmış ölçekler kullanılarak oluşturulmuştur. Çalışanların yetenek yönetimi algısını belirlemek için “Yetenek Yönetimi Ölçeği” Leyla Erat (2019)'ın yüksek lisans tezinden alınarak kullanılmıştır. Bu ölçeğin kuruma güven, öz yeterlilik algısı, kurum desteği ve operasyonel uyum, iş tatmini ve yetkinlik olmak üzere beş boyutu bulunmaktadır. İnovasyon ölçeği ise, Lina Karabetyan (2019)'ın doktora tezinden alınarak kullanılmıştır. Ölçekte hizmet inovasyon performansı tek boyutta 14 ifade ile ölçülmektedir. Araştırma verileri 2020 öncesi toplandığı için ayrıca anket etik iznine başvurulmamıştır.

Araştırmanın hipotezleri şu şekildedir.

H1: Yetenek yönetimi ve inovasyon istatistik anlamlı ilişkilidir.

H1a: Kurum desteği ve operasyonel uyum istatistik anlamlı ilişkilidir.

H1b: Kuruma güven ve inovasyon istatistik anlamlı ilişkilidir.

H1c: İş tatminini ve inovasyon istatistik anlamlı ilişkilidir.

H1d: Öz yeterlilik algısı ve inovasyon istatistik anlamlı ilişkilidir.

H1e: Yetkinlik ve inovasyon istatistik anlamlı ilişkilidir.

Araştırmanın analizleri SPSS 22 paket programı kullanılarak gerçekleştirilmiştir.

\subsection{Açıklayıcı Faktör Analizi ve Güvenilirlik Analizi Sonuçları}

Çalışanlara uygulanan inovasyon ve yetenek yönetimi ölçeklerinin geçerliliğini ve güvenilirliğini tespit etmek için açıklayıcı faktör analizi ile güvenilirlik analizi gerçekleştirilmektedir.

Çizelge 1. İnovasyon Ölçeği Açıklayıcı Faktör Analizi ve Güvenilirlik Analizi Sonuçları

\begin{tabular}{|c|c|c|c|c|}
\hline & $\begin{array}{l}\text { Faktör } \\
\text { Yükleri }\end{array}$ & $\begin{array}{l}\text { Varyans } \\
\text { Yüzdesi }\end{array}$ & $\begin{array}{l}\text { Cronbach } \\
\text { Alfa }\end{array}$ & $n$ \\
\hline 7. Bu kurum yeni hizmetler geliştirmek için uygun bir ortam sunmaktadır. & 0,732 & \multirow{14}{*}{44,697} & \multirow{14}{*}{0,901} & \multirow{14}{*}{14} \\
\hline $\begin{array}{l}\text { 9. Yeni hizmet projeleri yürürlüğe konulduğunda, yöneticiler ve ön plandaki hizmet personeli } \\
\text { yakın işbirliği içerisindedirler. }\end{array}$ & 0,727 & & & \\
\hline 13. Çalıştığım bölüm, yeni hizmetler geliştirilmesinde profesyoneldir. & 0,724 & & & \\
\hline $\begin{array}{l}\text { 4. Kurumumda, yenilikleri uygulamak için gerekli olan kaynakları güvence altında tutmaya } \\
\text { çalışırım. }\end{array}$ & 0,716 & & & \\
\hline 8. Bu kurumda tüm bölümler yeni işler geliştirmek için iyi bir etkileşime sahiptir. & 0,706 & & & \\
\hline 11. Bu kurum, yeni hizmet geliştirilmesi için bazı kaynaklarını tahsis etmektedir. & 0,692 & & & \\
\hline $\begin{array}{l}\text { 14. Çalıştığım bölüm tarafından geliştirilen yeni hizmetler, kaynakların kullanımı bakımından } \\
\text { etkin olur. }\end{array}$ & 0,690 & & & \\
\hline 5. Kurumumda, yeni fikirler geliştirmek için, uygulanabilir bir plan oluştururum. & 0,658 & & & \\
\hline 3. Kurumumda, yaratıcı fikirlerimi çalışma arkadaşlarıma anlatırım. & 0,658 & & & \\
\hline 1. Çalışırken işimle ilgili yeni hizmet tekniklerini araştırırım. & 0,628 & & & \\
\hline 10. Bu kurumda yeni işlerin geliştirilmesinde başarılı olan çalışanlar ödüllendirilir. & 0,615 & & & \\
\hline 2. Çalışırken yenilikçi düşünceler üretirim. & 0,600 & & & \\
\hline 12. Bu kurumun mevcut insan gücü, hizmetlerin geliştirilmesi için yeterlidir. & 0,599 & & & \\
\hline 6. Genel olarak kendimi çalıştığım bölümün yaratıcı bir üyesi olarak görürüm. & 0,587 & & & \\
\hline Kaiser Meyer Olkin (KMO) & 0,863 & & & \\
\hline
\end{tabular}


Çizelge 1'de görüldüğü üzere KMO testi \%86,3'dür. \%86,3>0,50 olduğu için veri seti faktör analizi için uygun olduğu söylenebilir. İkinci olarak bakılan test ise Bartlett testidir. Yapılan analiz sonucunda bu testinde anlamlı olduğu sonucuna varıldı $(p=0,000<0,01)$. Bu sonuç boyutlar arasındaki yüksek korelasyonun varlığını ortaya koymaktadır. Yani veri seti faktör analizi için uygundur. Güvenilirlik analizi sonucunda elde edilen genel Cronbach alfa katsayısı 0,901 olarak tespit edilmektedir. Bu sonuç ölçeğin yüksek güvenilirlikte olduğunu göstermektedir. Yapılan faktör analizi sonucunda tek faktör olduğu ortaya çıkmıştır. Faktör yükleri $0,732-0,587$ arasında değişmektedir ve varyans yüzdesi de 44,697'dir.

\section{Çizelge 2. Yetenek Yönetimi Ölçeği Açıklayıcı Faktör Analizi ve Güvenilirlik Analizi Sonuçları}

\begin{tabular}{|c|c|c|c|c|c|}
\hline & & $\begin{array}{l}\text { Faktör } \\
\text { Yükleri }\end{array}$ & $\begin{array}{l}\text { Varyans } \\
\text { Yüzdesi }\end{array}$ & $\begin{array}{l}\text { Cronbach } \\
\text { Alfa }\end{array}$ & $n$ \\
\hline \multirow{4}{*}{$\begin{array}{l}\text { Kurum Desteği ve Operasyonel } \\
\text { Uyum }\end{array}$} & $\begin{array}{l}\text { 14. Çalıştığım kurum kişisel eğitimim için yeterli desteği } \\
\text { sağlar. }\end{array}$ & 0,888 & \multirow{4}{*}{19,894} & \multirow{4}{*}{0,877} & \multirow{4}{*}{4} \\
\hline & $\begin{array}{l}\text { 13. Çalıştığım kurum personelin geliş̧imine yönelik } \\
\text { eğitimler düzenler. }\end{array}$ & 0,879 & & & \\
\hline & 15. Çalıştığım kurum yeterli maddi olanaklar sağlar. & 0,787 & & & \\
\hline & $\begin{array}{l}\text { 1. Çalıştığım kurum, işimi daha iyi yapmam konusunda } \\
\text { bana destek olur. }\end{array}$ & 0,723 & & & \\
\hline \multirow{4}{*}{ Kuruma Güven } & $\begin{array}{l}\text { 8. Çalıştığım birime uygun olarak, yeteneklerimi tam } \\
\text { kapasite ile kullandığımı düşünüyorum. }\end{array}$ & 0,754 & \multirow{4}{*}{14,707} & \multirow{4}{*}{0,786} & \multirow{4}{*}{4} \\
\hline & $\begin{array}{l}\text { 5. Çalıştığım kurum yönetiminin yeteneklerimden } \\
\text { yararlandığını düşünüyorum. }\end{array}$ & 0,744 & & & \\
\hline & $\begin{array}{l}\text { 6. Genel olarak işimden doyum sağladığımı } \\
\text { düşünüyorum. }\end{array}$ & 0,694 & & & \\
\hline & $\begin{array}{l}\text { 4. Çalıştığım kurum yönetimi, sorumluluklarını etkili bir } \\
\text { șekilde yerine getirmektedir. }\end{array}$ & 0,624 & & & \\
\hline \multirow{3}{*}{ İş Tatmini } & 20. İşim benim için önemlidir. & 0,857 & \multirow{3}{*}{14,657} & \multirow{3}{*}{0,802} & \multirow{3}{*}{3} \\
\hline & $\begin{array}{l}\text { 19. İşimi başarılı bir şekilde gerçekleştirdikten sonra } \\
\text { kendimi mutlu hissederim. }\end{array}$ & 0,849 & & & \\
\hline & $\begin{array}{l}\text { 18. Çalıştığım kurumun sektör içinde iyi bir yerde } \\
\text { bulunması, üzerimde olumlu etki uyandırır. }\end{array}$ & 0,735 & & & \\
\hline \multirow{3}{*}{ Öz Yeterlilik Alg1sı } & $\begin{array}{l}\text { 11. Çalıştığım birimde mesleki yeterliliklerim nedeniyle } \\
\text { görev yapmaktayım. }\end{array}$ & 0,849 & \multirow{3}{*}{12,946} & \multirow{3}{*}{0,784} & \multirow{3}{*}{3} \\
\hline & $\begin{array}{l}\text { 10. Çalıştığım birimde eğitim ve deneyimlerim nedeniyle } \\
\text { görev yapmaktayım. }\end{array}$ & 0,846 & & & \\
\hline & $\begin{array}{l}\text { 12. Çalıştığım birime uygun olarak, kendimi yetenekli } \\
\text { buluyorum. }\end{array}$ & 0,604 & & & \\
\hline \multirow{2}{*}{ Yetkinlik } & $\begin{array}{l}\text { 21. İşim için gereken becerilere uzmanlık seviyesinde } \\
\text { sahibim. }\end{array}$ & 0,805 & \multirow{2}{*}{10,260} & \multirow{2}{*}{0,745} & \multirow{2}{*}{2} \\
\hline & $\begin{array}{l}\text { 22. Bulunduğum birimde yeni fikirler geliştirip } \\
\text { uygularım. }\end{array}$ & 0,776 & & & \\
\hline
\end{tabular}

Çizelge 2'de görüldüğü üzere KMO testi \%82,8'dir. \%82,8>0,50 olduğu için veri seti faktör analizi için uygun olduğu söylenebilir. İkinci olarak bakılan test ise Bartlett testidir. Analiz sonucuna göre test anlamlıdır ( $p=0,000<0,01)$. Yani veri seti faktör analizi için uygundur. Güvenilirlik analizi sonucunda elde edilen genel Cronbach alfa katsayısı 0,874 olarak tespit edilmektedir. Bu sonuç ölçeğin yüksek güvenilirlikte olduğunu göstermektedir.

Yapılan faktör analizi sonucunda faktör yükü 0,50'nin altında (Kalaycı, 2008: 329) ve güvenilirlik analizi sonucunda Cronbach alfa değeri 0,20'nin altında olan altı ifade analize dahil edilmemektedir. 
Bu ifadeler olmadan yapılan faktör analizi sonucunda beş faktör ortaya çıkmıştır. İlk faktör kurum desteği ve operasyonel uyum faktörüdür, faktör yükleri 0,888-0,723 arasında değişmektedir ve varyans yüzdesi de 19,894'dür. Bu boyutun Cronbach alfa katsayısı 0,877 ile yüksek güvenilirdir. İkinci faktör kuruma güven faktörüdür, faktör yükleri 0,754-0,624 arasında değişmektedir ve varyans yüzdesi de 14,707'dir. Bu boyutun Cronbach alfa katsayısı 0,786 ile güvenilirdir. Üçüncü faktör iş tatmini faktörüdür, faktör yükleri 0,857-0,735 arasında değişmektedir ve varyans yüzdesi 14,657 'dir. Bu boyutun Cronbach alfa katsayısı 0,802 ile yüksek güvenilirdir. Dördüncü faktör öz yeterlilik algısı faktörüdür, faktör yükleri 0,849-0,604 arasında değişmektedir, varyans yüzdesi de 12,946'dir. Bu boyutun da Cronbach alfa katsayısı 0,784 ile güvenilirdir. Beşinci ve son faktör yetkinlik faktörüdür, faktör yükleri 0,805-0,776 arasında değişmektedir. Bu boyutun da Cronbach alfa katsayısı 0,745 ile güvenilirdir. Tüm faktörler toplam varyansın \% 72,5'ini $(72,464)$ açıklamaktadır.

\subsection{Ortalama, Standart Sapma, Çarpıklık ve Basıklık}

Değişkenlerin ortalama ve standart sapmaları ile normal dağılıma uygunluğunun tespiti için çarpıklık ve basıklık değerlerine çizelge 3'de yer verilmektedir.

\section{Çizelge 3. Değişkenlerin Ortalama, Standart Sapma, Basıklık ve Çarpıklık Değerleri}

\begin{tabular}{|c|c|c|c|c|c|c|}
\hline & \multirow{2}{*}{$\bar{X}$} & \multirow{2}{*}{ SS } & \multicolumn{2}{|c|}{ Çarpıklık } & \multicolumn{2}{|c|}{ Basiklık } \\
\hline & & & İstatistik & $\varepsilon_{s_{h}}$ & İstatistik & $\varepsilon_{s_{h}}$ \\
\hline İnovasyon & 3,83 & 0,618 & $-0,515$ & 0,165 & 0,240 & 0,328 \\
\hline Yetenek Yönetimi & 3,99 & 0,520 & $-0,621$ & 0,165 & 0,647 & 0,328 \\
\hline Kurum Desteği ve Operasyonel Uyum & 3,38 & 0,970 & $-0,575$ & 0,165 & $-0,230$ & 0,328 \\
\hline Kuruma Güven & 3,80 & 0,715 & $-0,779$ & 0,165 & 1,105 & 0,328 \\
\hline İş Tatmini & 4,66 & 0,412 & $-0,682$ & 0,165 & $-1,223$ & 0,328 \\
\hline Öz Yeterlilik Algısı & 4,26 & 0,593 & $-0,282$ & 0,165 & $-0,700$ & 0,328 \\
\hline Yetkinlik & 4,30 & 0,611 & $-0,416$ & 0,165 & $-0,704$ & 0,328 \\
\hline
\end{tabular}

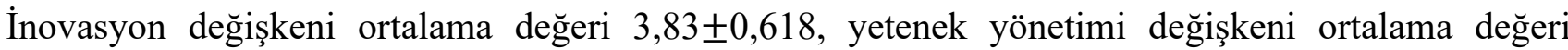
$3,99 \pm 0,520$, kurum desteği ve operasyonel uyum faktörü ortalama değeri $3,38 \pm 0,970$, kuruma güven

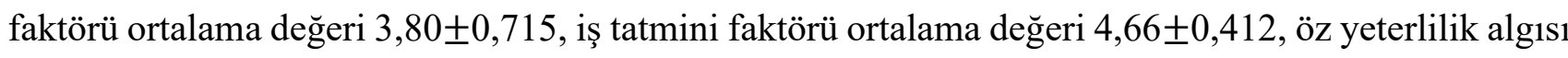

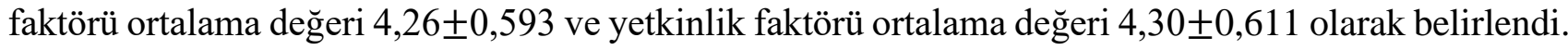
Tüm bu değişken ve faktörlerin basıklık ve çarpıklık değerleri $\pm 1,5$ aralığında yer aldığı için normal dağılıma yakındır (Kalaycı, 2008: 6). Bu sonuç fark testlerinde uygun olan parametrik testler kullanılması gerektiğini vermektedir. 


\section{BULGULAR}

\subsection{Demografik Sorulara İlişkin Bulgular}

Çalışanların cinsiyet, yaş, eğitim düzeyi, işyerindeki pozisyon, işyerindeki çalışma süresi ve toplam iş tecrübesinin frekans ve yüzde dağılımlarına yer verilmektedir. Elde edilen sonuçlar da değerlendirilmektedir.

\section{Çizelge 4. Demografik Dağılım}

\begin{tabular}{|c|c|c|c|}
\hline & & Frekans (n) & Yüzde (\%) \\
\hline & Kadın & 71 & 32,6 \\
\hline \multirow{4}{*}{ Cinsiyet } & Erkek & 147 & 67,4 \\
\hline & Toplam & 218 & 100,0 \\
\hline & 25 yaş ve altı & 35 & 16,1 \\
\hline & $26-30$ yas & 53 & 24,3 \\
\hline \multirow[t]{5}{*}{ Yaş } & $31-40$ yaş & 83 & 38,1 \\
\hline & 41 yaş ve üzeri & 47 & 21,6 \\
\hline & Toplam & 218 & 100,0 \\
\hline & Lise ve alt 1 & 44 & 20,2 \\
\hline & Üniversite & 141 & 64,7 \\
\hline \multirow{4}{*}{ Eğitim Düzeyi } & Yüksek Lisans ve Sonrası & 33 & 15,1 \\
\hline & Toplam & 218 & 100,0 \\
\hline & Çalış̧an & 120 & 55,0 \\
\hline & Alt Kademede Yönetici & 38 & 17,4 \\
\hline \multirow[t]{7}{*}{ İşyerindeki Pozisyon } & Orta Kademede Yönetici & 49 & 22,5 \\
\hline & Üst Kademede Yönetici & 11 & 5,0 \\
\hline & Toplam & 218 & 100,0 \\
\hline & 1 yildan az & 37 & 17,0 \\
\hline & $1-3$ y1l & 37 & 17,0 \\
\hline & $4-6$ y1l & 59 & 27,1 \\
\hline & 7 yıl ve üzeri & 85 & 39,0 \\
\hline \multirow{5}{*}{ İşyerindeki Çalışma Süresi } & Toplam & 218 & 100,0 \\
\hline & 3 yıl ve altı & 35 & 16,1 \\
\hline & $4-6$ y1l & 34 & 15,6 \\
\hline & 7 yıl ve üzeri & 149 & 68,3 \\
\hline & Toplam & 218 & 100,0 \\
\hline
\end{tabular}

Çalışanların \%67,4'ü (n=147) erkek iken \%32,6'sı $(n=71)$ kadındır. Bu kişilerin yaş dağılımlarına bakıldığında, \%38,1'i (n=83) 31-40 yaş arasında, \%24,3’ü (n=53) 26-30 yaş arasında, \%21,6'sı (n=47) 41 yaş ve üzeri, geriye kalan \%16,1’i de $(n=35) 25$ yaş ve altıdır. Eğitim düzeyi dağılımı için değerlendirme şu şekilde olmaktadır. Çalışanların \%64,7'si (n=141) üniversite, \%20,2'si (n=44) lise ve altı mezunu, \%15,1'i (n=33) yüksek lisans ve sonrası mezunu olduğu görülmektedir. Araştırmaya katılanların \%55,0’1 $(n=120)$ çalışan, \%22,5'i $(n=49)$ orta kademede yönetici, \%17,4'ü $(n=38)$ alt kademede yönetici, geriye kalan \%5,0’1 $(\mathrm{n}=11)$ üst kademede yönetici olarak görev almaktadır. Çalışan kişilerin \%39,0’1 (n=85) 7 yıl ve üzeri, \%27,1'i (n=59) 4-6 yıl arasında, \%17,0’1 (n=37) 1-3 yıl arasında, \%17,0’1 (n=37) 1 yıldan az işyerinde çalıştığı ortaya çıkmaktadır. Toplam çalışma süreleri incelendiğinde, çalışanların \%68,3’ü (n=149) 7 yıl ve üzeri, \%16,1’i (n=35) 3 yı1 ve altı, \%15,6`s1 $(n=34)$ 4-6 yıl arasında, geriye kalan \%15,6'sı $(n=34)$ 4-6 yıl arasında toplam iş tecrübesine sahiptir. 


\subsection{Fark Testleri}

İnovasyon ve boyutları, yetenek yönetimi ve boyutlarının cinsiyet, yaş, eğitim düzeyi, işyerindeki pozisyon, işyerindeki çalışma süresi ve toplam iş tecrübesine göre anlamlılığı Bağımsız Grup T testi ve Tek Yönlü Varyans (ANOVA) analizi yapılarak tespit edilmektedir.

\section{Çizelge 5. Cinsiyete Göre Değişkenlerin Farklılığı}

\begin{tabular}{|c|c|c|c|c|c|c|}
\hline & Cinsiyet & $n$ & $\overline{\bar{X}}$ & $S S$ & $t$ & $p$ \\
\hline \multirow{2}{*}{ İnovasyon } & Kadın & 71 & 3,82 & 0,632 & \multirow[b]{2}{*}{$-0,179$} & \multirow{2}{*}{0,858} \\
\hline & Erkek & 147 & 3,83 & 0,613 & & \\
\hline \multirow{2}{*}{ Yetenek Yönetimi } & Kadın & 71 & 4,01 & 0,515 & \multirow{2}{*}{0,275} & \multirow{2}{*}{0,784} \\
\hline & Erkek & 147 & 3,99 & 0,525 & & \\
\hline \multirow{2}{*}{ Kurum Desteği ve Operasyonel Uyum } & Kadın & 71 & 3,44 & 0,999 & \multirow{2}{*}{0,641} & \multirow{2}{*}{0,522} \\
\hline & Erkek & 147 & 3,35 & 0,958 & & \\
\hline \multirow{2}{*}{ Kuruma Güven } & Kadın & 71 & 3,84 & 0,659 & \multirow{2}{*}{0,589} & \multirow{2}{*}{0,557} \\
\hline & Erkek & 147 & 3,78 & 0,742 & & \\
\hline \multirow{2}{*}{ İş Tatmini } & Kadın & 71 & 4,61 & 0,438 & \multirow{2}{*}{$-1,333$} & \multirow{2}{*}{0,184} \\
\hline & Erkek & 147 & 4,68 & 0,397 & & \\
\hline \multirow{2}{*}{ Öz Yeterlilik Algısı } & Kadın & 71 & 4,24 & 0,555 & \multirow{2}{*}{$-0,273$} & \multirow{2}{*}{0,785} \\
\hline & Erkek & 147 & 4,27 & 0,613 & & \\
\hline \multirow{2}{*}{ Yetkinlik } & Kadın & 71 & 4,29 & 0,607 & \multirow{2}{*}{$-0,235$} & \multirow{2}{*}{0,814} \\
\hline & Erkek & 147 & 4,31 & 0,615 & & \\
\hline
\end{tabular}

Bağımsız Grup T Testi sonucunda, cinsiyete göre inovasyon, yetenek yönetimi, kurum desteği ve operasyonel uyum, kuruma güven, iş tatmini, öz yeterlilik algıs1, yetkinlik değişkenleri ortalama puanları arasında istatistiksel açıdan anlamlı bir farklılık tespit edilemedi $(\mathrm{p} \geq 0,05)$.

\section{Çizelge 6. Yaşa Göre Değişkenlerin Farklılığı}

\begin{tabular}{|c|c|c|c|c|c|c|c|c|}
\hline & & \multirow[t]{2}{*}{$n$} & \multirow[t]{2}{*}{$\bar{X}$} & \multirow[t]{2}{*}{ SS } & \multicolumn{2}{|c|}{$\begin{array}{c}\text { Homojenliğin } \\
\text { Levene Testi }\end{array}$} & \multicolumn{2}{|c|}{ ANOVA } \\
\hline & & & & & Levene İstatistiği & $p$ & $F$ & $p$ \\
\hline \multirow{5}{*}{ İnovasyon } & 25 yaş ve altı & 35 & 3,80 & 0,551 & \multirow{5}{*}{0,429} & \multirow{5}{*}{0,732} & \multirow{5}{*}{2,238} & \multirow{5}{*}{0,085} \\
\hline & $26-30$ yaş & 53 & 3,66 & 0,664 & & & & \\
\hline & $31-40$ yaş & 83 & 3,88 & 0,585 & & & & \\
\hline & 41 yaş ve üzeri & 47 & 3,95 & 0,642 & & & & \\
\hline & Toplam & 218 & 3,83 & 0,618 & & & & \\
\hline \multirow{5}{*}{ Yetenek Yönetimi } & 25 yaş ve altı & 35 & 3,98 & 0,554 & \multirow{5}{*}{0,324} & \multirow{5}{*}{0,808} & \multirow{5}{*}{1,88} & \multirow{5}{*}{0,13} \\
\hline & $26-30$ yaş & 53 & 3,92 & 0,539 & & & & \\
\hline & $31-40$ yaş & 83 & 3,97 & 0,519 & & & & \\
\hline & 41 yaş ve üzeri & 47 & 4,15 & 0,458 & & & & \\
\hline & Toplam & 218 & 3,99 & 0,520 & & & & \\
\hline \multirow{5}{*}{$\begin{array}{l}\text { Kurum Desteği ve } \\
\text { Operasyonel Uyum }\end{array}$} & 25 yaş ve altı & 35 & 3,59 & 0,919 & \multirow{5}{*}{1,968} & \multirow{5}{*}{0,120} & \multirow{5}{*}{2,483} & \multirow{5}{*}{0,062} \\
\hline & $26-30$ yaş & 53 & 3,22 & 1,080 & & & & \\
\hline & $31-40$ yaş & 83 & 3,27 & 0,964 & & & & \\
\hline & 41 yaş ve üzeri & 47 & 3,63 & 0,831 & & & & \\
\hline & Toplam & 218 & 3,38 & 0,970 & & & & \\
\hline \multirow{5}{*}{ Kuruma Güven } & 25 yaş ve altı & 35 & 3,82 & 0,792 & \multirow{5}{*}{1,757} & \multirow{5}{*}{0,156} & \multirow{5}{*}{0,949} & \multirow{5}{*}{0,418} \\
\hline & $26-30$ yaş & 53 & 3,75 & 0,708 & & & & \\
\hline & $31-40$ yaş & 83 & 3,74 & 0,758 & & & & \\
\hline & 41 yaş ve üzeri & 47 & 3,95 & 0,571 & & & & \\
\hline & Toplam & 218 & 3,80 & 0,715 & & & & \\
\hline \multirow{5}{*}{ İş Tatmini } & 25 yaş ve altı & 35 & 4,67 & 0,404 & & & & \\
\hline & $26-30$ yaş & 53 & 4,65 & 0,426 & & & & \\
\hline & $31-40$ yaş & 83 & 4,67 & 0,403 & 0,844 & 0,471 & 0,030 & 0,993 \\
\hline & 41 yaş ve üzeri & 47 & 4,65 & 0,428 & & & & \\
\hline & Toplam & 218 & 4,66 & 0,412 & & & & \\
\hline & 25 yaş ve altı & 35 & 4,05 & 0,567 & & & & \\
\hline & $26-30$ yaş & 53 & 4,18 & 0,591 & & & & \\
\hline Öz Yeterlilik Algısı & $31-40$ yaş & 83 & 4,31 & 0,627 & 1,633 & 0,183 & 3,448 & 0,018 \\
\hline & 41 yaş ve üzeri & 47 & 4,43 & 0,501 & & & & \\
\hline & Toplam & 218 & 4,26 & 0,593 & & & & \\
\hline & 25 yaş ve altı & 35 & 4,06 & 0,715 & & & & \\
\hline & 26-30 yaş & 53 & 4,29 & 0,654 & & & & \\
\hline Yetkinlik & $31-40$ yaş & 83 & 4,34 & 0,530 & 1,726 & 0,163 & 2,793 & $\mathbf{0 , 0 4 1}$ \\
\hline & 41 yaş ve üzeri & 47 & 4,44 & 0,577 & & & & \\
\hline & Toplam & 218 & 4,30 & 0,611 & & & & \\
\hline
\end{tabular}

Tek Yönlü Varyans (ANOVA) analizi sonucunda yaşa göre inovasyon, yetenek yönetimi, kurum desteği ve operasyonel uyum, kuruma güven, iş tatmini değişkenlerinin ortalama puanları arasında 
anlamlı bir farklılık tespit edilmezken ( $p \geq 0,05)$, yaşa göre öz yeterlilik algısı $(p=0,018 \leq 0,05)$ ve yetkinlik $(\mathrm{p}=0,041 \leq 0,05)$ faktörlerinin ortalama puanları arasında istatistiksel olarak anlamlı bir farklılık belirlendi. Yaşa göre öz yeterlilik algısı ve yetkinlik faktör değişkenlerinin homojenliğine ilişkin Levene testi sonucu anlamlıdır $(\mathrm{p} \geq 0,05)$. Bu sonuç yaş grupları arasında karşılaştırma yapılacağı anlamına gelmektedir. İlk önce öz yeterlilik algısının yaş grupları arasındaki karşılaştırması değerlendirilmektedir. Çoklu karşılaştırma modeli olarak Scheffe kullanılmaktadır. Bu model 25 yaş ve altı çalışanların öz yeterlilik algısı 45 yaş ve üzeri çalışanlara göre farklılık olduğu sonucunu ortaya koymaktadır. Ortalama değer incelendiğindeyse 45 yaş ve üzeri çalışanların öz yeterlilik algısının 25 yaş ve altı çalışanlara göre daha yüksek olduğu görülmekte ve daha tecrübeli olmalarının bu algıyı artırdığı düşünülebilir.

Son olarak da yetkinliğin yaş grupları arasındaki karşılaştırması değerlendirilmektedir. Çoklu karşılaştırma modeli olarak Tukey kullanılmaktadır. Bu model 25 yaş altı çalışanların yetkinliğinin 45 yaş ve üstü çalışanlara göre farklılık olduğu sonucunu ortaya koymaktadır. Ortalama değer incelendiğindeyse 45 yaş ve üstü çalışanların 25 yaş ve altı çalışanlara göre iş tecrübesi, o süreçte alınan iş ile ilgili eğitimler vb. yetkinliklerinin daha yüksek olduğu görülmektedir.

\section{Çizelge 7. Eğitim Düzeyine Göre Değişkenlerin Farklılığı}

\begin{tabular}{|c|c|c|c|c|c|c|c|c|}
\hline & & \multirow{2}{*}{$n$} & \multirow{2}{*}{$\bar{X}$} & \multirow{2}{*}{$S S$} & \multicolumn{2}{|c|}{ Homojenliğin Levene Testi } & \multicolumn{2}{|c|}{ ANOVA } \\
\hline & & & & & Levene İstatistiği & $p$ & $F$ & $p$ \\
\hline \multirow{4}{*}{ İnovasyon } & Lise ve altı & 44 & 3,80 & 0,606 & \multirow{4}{*}{0,730} & \multirow{4}{*}{0,483} & \multirow{4}{*}{0,779} & \multirow{4}{*}{0,460} \\
\hline & Üniversite & 141 & 3,81 & 0,611 & & & & \\
\hline & Yüksek Lisans ve üzeri & 33 & 3,95 & 0,665 & & & & \\
\hline & Toplam & 218 & 3,83 & 0,618 & & & & \\
\hline \multirow{4}{*}{ Yetenek Yönetimi } & Lise ve altı & 44 & 4,00 & 0,485 & \multirow{4}{*}{1,213} & \multirow{4}{*}{0,299} & \multirow{4}{*}{0,032} & \multirow{4}{*}{0,969} \\
\hline & Üniversite & 141 & 3,99 & 0,517 & & & & \\
\hline & Yüksek Lisans ve üzeri & 33 & 4,01 & 0,592 & & & & \\
\hline & Toplam & 218 & 3,99 & 0,520 & & & & \\
\hline \multirow{4}{*}{$\begin{array}{l}\text { Kurum Desteği ve } \\
\text { Operasyonel Uyum }\end{array}$} & Lise ve alt 1 & 44 & 3,45 & 0,962 & \multirow{4}{*}{0,496} & \multirow{4}{*}{0,610} & \multirow{4}{*}{0,418} & \multirow{4}{*}{0,659} \\
\hline & Üniversite & 141 & 3,39 & 0,940 & & & & \\
\hline & Yüksek Lisans ve üzeri & 33 & 3,25 & 1,115 & & & & \\
\hline & Toplam & 218 & 3,38 & 0,970 & & & & \\
\hline \multirow{4}{*}{ Kuruma Güven } & Lise ve alt 1 & 44 & 3,86 & 0,582 & \multirow{4}{*}{2,922} & \multirow{4}{*}{0,056} & \multirow{4}{*}{0,547} & \multirow{4}{*}{0,579} \\
\hline & Üniversite & 141 & 3,81 & 0,708 & & & & \\
\hline & Yüksek Lisans ve üzeri & 33 & 3,69 & 0,897 & & & & \\
\hline & Toplam & 218 & 3,80 & 0,715 & & & & \\
\hline \multirow{4}{*}{ İş Tatmini } & Lise ve altı & 44 & 4,61 & 0,443 & \multirow{4}{*}{5,034} & \multirow{4}{*}{0,007} & \multirow{4}{*}{1,730} & \multirow{4}{*}{0,180} \\
\hline & Üniversite & 141 & 4,65 & 0,416 & & & & \\
\hline & Yüksek Lisans ve üzeri & 33 & 4,78 & 0,330 & & & & \\
\hline & Toplam & 218 & 4,66 & 0,412 & & & & \\
\hline & Lise ve altı & 44 & 4,16 & 0,591 & & & & \\
\hline Öz Yeterlilik Alo1si & Üniversite & 141 & 4,25 & 0,573 & & & & \\
\hline UZ Y etermIIK AIgIsI & Yüksek Lisans ve üzeri & 33 & 4,42 & 0,663 & 1,604 & 0,204 & 1,927 & 0,148 \\
\hline & Toplam & 218 & 4,26 & 0,593 & & & & \\
\hline & Lise ve alt 1 & 44 & 4,35 & 0,687 & & & & \\
\hline Yetkinlik & Üniversite & 141 & 4,25 & 0,596 & & & & 0.192 \\
\hline YetkınııK & Yüksek Lisans ve üzeri & 33 & 4,45 & 0,550 & $2,3 / 1$ & 0,096 & 1,664 & 0,192 \\
\hline & Toplam & 218 & 4,30 & 0,611 & & & & \\
\hline
\end{tabular}

ANOVA testi sonucunda eğitim durumuna göre inovasyon, yetenek yönetimi, kurum desteği ve operasyonel uyum, kuruma güven, iş tatmini, özyeterlilik algısı, yetkinlik değişkenlerinin ortalama puanları arasında anlamlı farklılık belirlenmedi $(\mathrm{p} \geq 0,05)$. 


\begin{tabular}{|c|c|c|c|c|c|c|c|c|}
\hline & & \multirow{2}{*}{$n$} & \multirow{2}{*}{$\bar{X}$} & \multirow{2}{*}{$S S$} & \multicolumn{2}{|c|}{ Homojenliğin Levene Testi } & \multicolumn{2}{|c|}{ ANOVA } \\
\hline & & & & & Levene İstatistiği & $p$ & $F$ & $p$ \\
\hline \multirow{5}{*}{ İnovasyon } & Çalışan & 120 & 3,77 & 0,600 & \multirow{5}{*}{0,837} & \multirow{5}{*}{0,475} & \multirow{5}{*}{1,760} & \multirow{5}{*}{0,156} \\
\hline & Alt Kademede Yönetici & 38 & 3,76 & 0,686 & & & & \\
\hline & Orta Kademede Yönetici & 49 & 3,96 & 0,626 & & & & \\
\hline & Üst Kademede Yönetici & 11 & 4,06 & 0,416 & & & & \\
\hline & Toplam & 218 & 3,83 & 0,618 & & & & \\
\hline \multirow{5}{*}{ Yetenek Yönetimi } & Çalışan & 120 & 3,94 & 0,508 & \multirow{5}{*}{1,187} & \multirow{5}{*}{0,316} & \multirow{5}{*}{2,209} & \multirow{5}{*}{0,088} \\
\hline & Alt Kademede Yönetici & 38 & 3,98 & 0,578 & & & & \\
\hline & Orta Kademede Yönetici & 49 & 4,08 & 0,517 & & & & \\
\hline & Üst Kademede Yönetici & 11 & 4,29 & 0,331 & & & & \\
\hline & Toplam & 218 & 3,99 & 0,520 & & & & \\
\hline \multirow{5}{*}{$\begin{array}{l}\text { Kurum Desteği ve } \\
\text { Operasyonel Uyum }\end{array}$} & Çalışan & 120 & 3,29 & 0,995 & \multirow{5}{*}{2,103} & \multirow{5}{*}{0,101} & \multirow{5}{*}{2,4} & \multirow{5}{*}{0,069} \\
\hline & Alt Kademede Yönetici & 38 & 3,32 & 1,018 & & & & \\
\hline & Orta Kademede Yönetici & 49 & 3,52 & 0,890 & & & & \\
\hline & Üst Kademede Yönetici & 11 & 4,02 & 0,586 & & & & \\
\hline & Toplam & 218 & 3,38 & 0,970 & & & & \\
\hline \multirow{5}{*}{ Kuruma Güven } & Çalışan & 120 & 3,78 & 0,709 & \multirow{5}{*}{1,561} & \multirow{5}{*}{0,200} & \multirow{5}{*}{0,394} & \multirow{5}{*}{0,757} \\
\hline & Alt Kademede Yönetici & 38 & 3,76 & 0,786 & & & & \\
\hline & Orta Kademede Yönetici & 49 & 3,84 & 0,739 & & & & \\
\hline & Üst Kademede Yönetici & 11 & 4,00 & 0,387 & & & & \\
\hline & Toplam & 218 & 3,80 & 0,715 & & & & \\
\hline \multirow{5}{*}{ İş Tatmini } & Çalışan & 120 & 4,63 & 0,422 & & & & \\
\hline & Alt Kademede Yönetici & 38 & 4,60 & 0,466 & & & & \\
\hline & Orta Kademede Yönetici & 49 & 4,75 & 0,344 & 6,651 & 0,000 & 1,435 & 0,233 \\
\hline & Üst Kademede Yönetici & 11 & 4,76 & 0,336 & & & & \\
\hline & Toplam & 218 & 4,66 & 0,412 & & & & \\
\hline & Çalışan & 120 & 4,20 & 0,612 & & & & \\
\hline & Alt Kademede Yönetici & 38 & 4,36 & 0,545 & & & & \\
\hline Öz Yeterlilik Algısı & Orta Kademede Yönetici & 49 & 4,28 & 0,595 & 0,641 & 0,589 & 1,315 & 0,270 \\
\hline & Üst Kademede Yönetici & 11 & 4,48 & 0,503 & & & & \\
\hline & Toplam & 218 & 4,26 & 0,593 & & & & \\
\hline & Çalışan & 120 & 4,20 & 0,636 & & & & \\
\hline & Alt Kademede Yönetici & 38 & 4,45 & 0,579 & & & & \\
\hline Yetkinlik & Orta Kademede Yönetici & 49 & 4,43 & 0,550 & 0,607 & 0,611 & 2,806 & 0,041 \\
\hline & Üst Kademede Yönetici & 11 & 4,41 & 0,539 & & & & \\
\hline & Toplam & 218 & 4,30 & 0,611 & & & & \\
\hline
\end{tabular}

Test sonucunda, pozisyona göre inovasyon, yetenek yönetimi, kurum desteği ve operasyonel uyum, kuruma güven, iş tatmini, öz yeterlilik değişkenlerinin ortalama puanları arasına istatistiksel olarak anlamlı bir farklılık tespit edilmedi $(p \geq 0,05)$. Çalışanın pozisyonuna göre yetkinlik değişkeninin ortalama puanları arasında anlamlı bir farklılık belirlendi $(\mathrm{p}=0,041 \leq 0,05)$.

Pozisyona göre yetkinlik faktör değişkeninin homojenliğine ilişkin Levene testi sonucu anlamlıdır $(\mathrm{p} \geq 0,05)$. Bu sonuç pozisyon grupları arasında karşıllaştırma yapılacağı anlamına gelmektedir. Yetkinliğin pozisyon grupları arasındaki karşılaştırması değerlendirilmektedir. Çoklu karşılaştırma modeli olarak LSD kullanılmaktadır. Bu model çalışanın yetkinliğinin alt kademede yöneticinin yetkinliğine göre ve çalışanın yetkinliğinin orta kademede yöneticiye göre farklılık olduğu sonucunu ortaya koymaktadır. Ortalama değer incelendiğindeyse alt kademede yöneticinin yetkinliğinin çalışana göre ve orta kademede yöneticinin çalışana göre yetkinliğinin daha yüksek olduğu görülmektedir.

Çizelge 9. İşyerindeki Çalışma Süresine Göre Değişkenlerin Farklılı̆̆ı

\begin{tabular}{|c|c|c|c|c|c|c|c|c|}
\hline & & \multirow{2}{*}{$n$} & \multirow{2}{*}{$\bar{X}$} & \multirow{2}{*}{$S S$} & \multicolumn{2}{|c|}{ Homojenliğin Levene Testi } & \multicolumn{2}{|c|}{ ANOVA } \\
\hline & & & & & Levene İstatistiği & $p$ & $F$ & $p$ \\
\hline \multirow{5}{*}{ İnovasyon } & 1 yildan az & 37 & 3,71 & 0,575 & \multirow{5}{*}{0,496} & \multirow{5}{*}{0,686} & \multirow{5}{*}{1,824} & \multirow{5}{*}{0,144} \\
\hline & $1-3$ yil & 37 & 3,68 & 0,668 & & & & \\
\hline & 4-6 y1l & 59 & 3,91 & 0,600 & & & & \\
\hline & 7 yıl ve üzeri & 85 & 3,89 & 0,616 & & & & \\
\hline & Toplam & 218 & 3,83 & 0,618 & & & & \\
\hline
\end{tabular}




\begin{tabular}{|c|c|c|c|c|c|c|c|c|}
\hline \multirow{5}{*}{ Yetenek Yönetimi } & 1 yıldan az & 37 & 3,86 & 0,527 & \multirow{5}{*}{0,432} & \multirow{5}{*}{0,731} & \multirow{5}{*}{3,949} & \multirow{5}{*}{0,009} \\
\hline & 1-3 y1l & 37 & 3,80 & 0,503 & & & & \\
\hline & $4-6$ y1l & 59 & 4,07 & 0,499 & & & & \\
\hline & 7 yil ve üzeri & 85 & 4,09 & 0,513 & & & & \\
\hline & Toplam & 218 & 3,99 & 0,520 & & & & \\
\hline \multirow{5}{*}{$\begin{array}{l}\text { Kurum Desteği ve Operasyonel } \\
\text { Uyum }\end{array}$} & 1 yildan az & 37 & 3,31 & 1,002 & \multirow{5}{*}{0,333} & \multirow{5}{*}{0,801} & \multirow{5}{*}{1,412} & \multirow{5}{*}{0,240} \\
\hline & $1-3$ y1l & 37 & 3,11 & 0,912 & & & & \\
\hline & $4-6$ y1l & 59 & 3,48 & 0,937 & & & & \\
\hline & 7 yil ve üzeri & 85 & 3,46 & 0,995 & & & & \\
\hline & Toplam & 218 & 3,38 & 0,970 & & & & \\
\hline \multirow{5}{*}{ Kuruma Güven } & 1 yıldan az & 37 & 3,71 & 0,749 & \multirow{5}{*}{0,315} & \multirow{5}{*}{0,815} & \multirow{5}{*}{1,915} & \multirow{5}{*}{0,128} \\
\hline & $1-3$ yll & 37 & 3,60 & 0,673 & & & & \\
\hline & 4-6 y1l & 59 & 3,82 & 0,760 & & & & \\
\hline & 7 yil ve üzeri & 85 & 3,91 & 0,673 & & & & \\
\hline & Toplam & 218 & 3,80 & 0,715 & & & & \\
\hline \multirow{5}{*}{ İş Tatmini } & 1 yildan az & 37 & 4,65 & 0,415 & \multirow{5}{*}{0,779} & \multirow{5}{*}{0,507} & \multirow{5}{*}{1,145} & \multirow{5}{*}{0,332} \\
\hline & $1-3$ y1l & 37 & 4,57 & 0,422 & & & & \\
\hline & 4-6 y1l & 59 & 4,64 & 0,391 & & & & \\
\hline & 7 yil ve üzeri & 85 & 4,71 & 0,418 & & & & \\
\hline & Toplam & 218 & 4,66 & 0,412 & & & & \\
\hline \multirow{5}{*}{ Öz Yeterlilik Algısı } & 1 yıldan az & 37 & 4,08 & 0,626 & \multirow{5}{*}{0,147} & \multirow{5}{*}{0,932} & \multirow{5}{*}{3,199} & \multirow{5}{*}{$\mathbf{0 , 0 2 4}$} \\
\hline & 1-3 y1l & 37 & 4,11 & 0,634 & & & & \\
\hline & $4-6$ y1l & 59 & 4,39 & 0,547 & & & & \\
\hline & 7 yil ve üzeri & 85 & 4,31 & 0,569 & & & & \\
\hline & Toplam & 218 & 4,26 & 0,593 & & & & \\
\hline \multirow{5}{*}{ Yetkinlik } & 1 yildan az & 37 & 4,00 & 0,540 & \multirow{5}{*}{1,753} & \multirow{5}{*}{0,157} & \multirow{5}{*}{6,905} & \multirow{5}{*}{0,000} \\
\hline & $1-3$ y1l & 37 & 4,11 & 0,689 & & & & \\
\hline & $4-6$ y1l & 59 & 4,42 & 0,556 & & & & \\
\hline & 7 yll ve üzeri & 85 & 4,44 & 0,581 & & & & \\
\hline & Toplam & 218 & 4,30 & 0,611 & & & & \\
\hline
\end{tabular}

Yapılan analiz sonucunda elde edilen değerler yukarıdaki çizelgede yer almaktadır. İnceleme sonucunda işyerindeki çalışma süresine göre inovasyon, kurum desteği ve operasyonel uyum, kuruma güven ve iş tatmini değişkenlerinin ortalama puanları arasında anlamlı bir farklılık belirlenmezken, işyerindeki çalışma süresine göre yetenek yönetimi $(p=0,009 \leq 0,01)$, öz yeterlilik algıs1 $(\mathrm{p}=0,024 \leq 0,05)$, yetkinlik $(\mathrm{p}=0,000 \leq 0,01)$ ortalama puanları arasında anlamlı bir farklılık tespit edildi.

İşyerindeki çalışma süresine göre yetenek yönetimi değişkeninin, öz yeterlilik algısı ile yetkinlik faktörlerinin homojenliğine ilişkin Levene testi sonuçları anlamlıdır ( $\mathrm{p} \geq 0,05)$. Bu sonuç işyerindeki çalışma süresi grupları arasında karşılaştırma yapılacağı anlamına gelmektedir.

İlk önce yetenek yönetimi değişkeninin işyerindeki çalışma süresi grupları arasındaki karşılaştırması değerlendirilmektedir. Çoklu karşılaştırma modeli olarak Tukey kullanılmaktadır. Bu model 1-3 yıl arasında işyerinde çalışanların yetenek yönetiminin ile 7 yıl ve üzeri işyerinde çalışan yetenek yönetimine göre farklılık olduğu sonucunu ortaya koymaktadır. Ortalama değer incelendiğindeyse 7 yıl ve üzeri işyerinde çalışanların yetenek yönetiminin 1-3 yıl arasında işyerinde çalışanlara göre daha yüksek olduğu görülmektedir.

İkinci olarak öz yeterlilik algısının işyerindeki çalışma süresi grupları arasındaki karşılaştırması değerlendirilmektedir. Çoklu karşılaştırma modeli olarak LSD kullanılmaktadır. Bu model, 1 yıldan az işyerinde çalışanların öz yeterlilik algılarının 4-6 yıl arasında işyerinde çalışanlara göre; 1-3 yıl arasında işyerinde çalışanların öz yeterlilik algılarının 4-6 yıl arasında işyerinde çalışanlara göre 
farklılık gösterdiği sonucunu vermektedir. Tablodaki ortalama değeler incelendiğindeyse, 4-6 yıl arasında işyerinde çalışanların 1 yıldan az işyerinde çalışanlara göre öz yeterlilik algıları; 4-6 yıl arasında işyerinde çalışanların 1-3 yıl arasında çalışanlara göre yeterlilik algıları daha yüksek olduğu görülmektedir. Son olarak yetkinliğin işyerindeki çalışma süresi grupları arasındaki karşılaştırılması değerlendirilmektedir. Çoklu karşılaştırma modeli olarak Tukey HSD kullanılmaktadır. Bu model, 1 yıldan az işyerinde çalışanların yetkinliklerinin 4-6 yıl arasında işyerinde çalışanlara göre; 1 yıldan az işyerinde çalışanların yetkinliklerinin 7 yıl ve üzeri işyerinde çalışanlara göre farklılık gösterdiği sonucunu vermektedir. Ortalama değerler incelendiğinde, 4-6 yıl arasında işyerinde çalışanların 1 yıldan az işyerinde çalışanlara göre; 7 yıl ve üzeri işyerinde çalışanların 1 yıldan az işyerinde çalışanlara göre yetkinlikleri daha yüksektir.

Çizelge 10. Toplam İş Tecrübesine Göre Değişkenlerin Farklılığı

\begin{tabular}{|c|c|c|c|c|c|c|c|c|}
\hline & & \multirow{2}{*}{$n$} & \multirow{2}{*}{$\bar{X}$} & \multirow{2}{*}{$S S$} & \multicolumn{2}{|c|}{ Homojenliğin Levene Testi } & \multicolumn{2}{|c|}{ ANOVA } \\
\hline & & & & & Levene İstatistiği & $p$ & $F$ & $p$ \\
\hline \multirow{4}{*}{ İnovasyon } & 3 y1l ve altı & 35 & 3,76 & 0,607 & \multirow{4}{*}{1,347} & \multirow{4}{*}{0,262} & \multirow{4}{*}{3,775} & \multirow{4}{*}{$\mathbf{0 , 0 2 4}$} \\
\hline & $4-6$ y1l & 34 & 3,59 & 0,710 & & & & \\
\hline & 7 y1l ve üstü & 149 & 3,90 & 0,586 & & & & \\
\hline & Toplam & 218 & 3,83 & 0,618 & & & & \\
\hline \multirow{4}{*}{ Yetenek Yönetimi } & 3 y1l ve altı & 35 & 3,86 & 0,513 & \multirow{4}{*}{1,548} & \multirow{4}{*}{0,215} & \multirow{4}{*}{3,536} & \multirow{4}{*}{$\mathbf{0 , 0 3 1}$} \\
\hline & 4-6 y1l & 34 & 3,86 & 0,616 & & & & \\
\hline & 7 y1l ve üstü & 149 & 4,06 & 0,489 & & & & \\
\hline & Toplam & 218 & 3,99 & 0,520 & & & & \\
\hline \multirow{4}{*}{$\begin{array}{l}\text { Kurum Desteği ve Operasyonel } \\
\text { Uyum }\end{array}$} & 3 y1l ve alt1 & 35 & 3,44 & 0,918 & \multirow{4}{*}{0,719} & \multirow{4}{*}{0,489} & \multirow{4}{*}{0,679} & \multirow{4}{*}{0,508} \\
\hline & $4-6$ y1l & 34 & 3,21 & 1,044 & & & & \\
\hline & 7 y1l ve üstü & 149 & 3,41 & 0,967 & & & & \\
\hline & Toplam & 218 & 3,38 & 0,970 & & & & \\
\hline \multirow{4}{*}{ Kuruma Güven } & 3 y1l ve altı & 35 & 3,76 & 0,786 & \multirow{4}{*}{0,527} & \multirow{4}{*}{0,591} & \multirow{4}{*}{1,901} & \multirow{4}{*}{0,152} \\
\hline & $4-6$ y1l & 34 & 3,60 & 0,718 & & & & \\
\hline & 7 y1l ve üstü & 149 & 3,86 & 0,693 & & & & \\
\hline & Toplam & 218 & 3,80 & 0,715 & & & & \\
\hline \multirow{4}{*}{ İş Tatmini } & 3 y1l ve altı & 35 & 4,59 & 0,421 & \multirow{4}{*}{0,408} & \multirow{4}{*}{0,666} & \multirow{4}{*}{0,943} & \multirow{4}{*}{0,391} \\
\hline & 4-6 y1l & 34 & 4,62 & 0,427 & & & & \\
\hline & 7 y1l ve üstü & 149 & 4,68 & 0,406 & & & & \\
\hline & Toplam & 218 & 4,66 & 0,412 & & & & \\
\hline & 3 y1l ve altı & 35 & 3,92 & 0,499 & & & & \\
\hline Öz Yeterlilik Alo 1 sı & 4-6 y1l & 34 & 4,23 & 0,665 & & & & \\
\hline OZ Y eterlil1k Algisı & 7 yıl ve üstü & 149 & 4,35 & 0,571 & 3,06 & 0,049 & 7,720 & 0,001 \\
\hline & Toplam & 218 & 4,26 & 0,593 & & & & \\
\hline & 3 y1l ve altı & 35 & 3,87 & 0,668 & & & & \\
\hline Yetkinlik & 4-6 y1l & 34 & 4,22 & 0,654 & & & & \\
\hline YetkinııK & 7 yıl ve üstü & 149 & 4,42 & 0,538 & 1,589 & 0,207 & 13,248 & 0,000 \\
\hline & Toplam & 218 & 4,30 & 0,611 & & & & \\
\hline
\end{tabular}

Analiz sonucunda, toplam iş tecrübesine göre kurum desteği ve operasyonel uyum, kuruma güven ve iş tatmini değişkenlerinin ortalama puanları arasında anlamlı bir farklılık rastlanmamaktadır $(\mathrm{p} \geq 0,05)$. Toplam iş tecrübesine göre inovasyon $(p=0,024 \leq 0,05)$, yetenek yönetimi $(p=0,031 \leq 0,05)$, öz yeterlilik alg1sı $(\mathrm{p}=0,001 \leq 0,01)$ ve yetkinlik $(\mathrm{p}=0,000 \leq 0,01)$ değişkenlerinin ortalama puanları arasında anlamlı bir farklılık tespit edilmektedir.

İşyerindeki toplam iş tecrübesine göre inovasyon ve yetenek yönetimi değişkeninin, yetkinlik faktörlerinin homojenliğine ilişkin Levene testi sonuçları anlamlıdır ( $p \geq 0,05)$. Sadece toplam iş tecrübesine göre yetkinlik faktörünün homojenliğine ilişkin Levene testi sonuçları anlamlı değildir 
$(\mathrm{p} \leq 0,05)$. Anlamlı Levene testi sonuçlarına göre toplam iş tecrübesi grupları arasında karşılaştırma yapılacağı anlamına gelmektedir.

İlk önce inovasyon değişkeninin toplam iş tecrübesi grupları arasındaki karşılaştırması değerlendirilmektedir. Çoklu karşılaştırma modeli olarak Tukey HSD kullanılmaktadır. Bu model 4-6 yıl arasında toplam iş tecrübesine sahip çalışanların inovasyona yönelik algılarının 7 yıl ve üzeri toplam iş tecrübesine sahip çalışanlara göre farkl1lık gösterdiği sonucunu ortaya koymaktadır. Ortalama değer incelendiğindeyse 7 yıl ve üzeri toplam iş tecrübesine sahip çalışanların inovasyona yönelik algılarının 4-6 yıl arasında toplam iş tecrübesine sahip çalışanlara göre daha yüksek olduğu görülmektedir.

İkinci olarak yetenek yönetiminin toplam iş tecrübesi grupları arasındaki karşılaştırması değerlendirilmektedir. Çoklu karşılaştırma modeli olarak LSD kullanılmaktadır. Bu model, 3 yıl ve altı toplam iş tecrübesine sahip çalışanların yetenek yönetimlerinin 7 yıl ve üzeri toplam iş tecrübesine sahip çalışanlara göre farklılık gösterdiği sonucunu vermektedir. Tablodaki ortalama değeler incelendiğindeyse, 7 yıl ve üstü toplam iş tecrübesine sahip çalışanların 3 yıl ve altı toplam iş tecrübesine sahip çalışanlara göre yetenek yönetimlerinin daha yükssek olduğu görülmektedir.

Üçüncü olarak öz yeterlilik algıları değişkeninin toplam iş tecrübesi grupları arasındaki karşılaştırması değerlendirilmektedir. İstatistik anlamlı farklılık çıktığında, hangi grupların birbirinden farklı olduğuna bakmak için post-hoc testlerini kullanmak gerekmektedir. Eğer gruplararası varyanslar eşit değilse Tamhane's T2 testine başvurulur. Bu karşılaştırmada grup varyansları eşit olmadığ1 için Tamhane's T2 kullanılmıştır. Bu model, 3 yıl ve altı toplam iş tecrübesine sahip çalışanların öz yeterlilik algılarının 7 yıl ve üzeri toplam iş tecrübesine sahip çalışanlara göre farklılık gösterdiği sonucunu vermektedir. Tablodaki ortalama değeler incelendiğinde ise, 7 yıl ve üstü toplam iş tecrübesine sahip çalışanların 3 yıl ve altı toplam iş tecrübesine sahip çalışanlara göre öz yeterlilik algıları daha yüksek olduğu görülmektedir.

Son olarak yetkinlik değişkeninin toplam iş tecrübesi grupları arasındaki karşılaştırması değerlendirilmektedir. Çoklu karşılaştırma modeli olarak Tukey HSD kullanılmaktadır. Bu model, 3 yıl ve altı toplam iş tecrübesine sahip çalışanların yetkinliğinin 4-6 yıl arasında toplam iş tecrübesine sahip çalışanlara göre; 3 yıl ve altı toplam iş tecrübesine sahip çalışanların 7 yıl ve üzeri toplam iş tecrübesine sahip çalışanlara göre farklılık gösterdiği sonucunu vermektedir. Tablodaki ortalama değeler incelendiğindeyse, 4-6 yıl arasında toplam iş tecrübesine sahip çalışanların 3 yıl ve altı toplam iş tecrübesine sahip çalışanlara göre; 7 yıl ve üstü toplam iş tecrübesine sahip çalışanların 3 yıl ve altı 
toplam iş tecrübesine sahip çalışanlara göre yetkinliklerinin daha yüksek olduğu, genel olarak tüm farklılık olanlarda iş tecrübesi önemli fark yaratıyor görünüyor.

\subsection{Basit ve Çoklu Doğrusal Regresyon Analizi}

Çalışanların yetenek yönetiminin inovasyona etkisini belirlemek için Basit Doğrusal Regresyon analizi yapılmaktadır.

\section{Çizelge 11. Basit Doğrusal Regresyon Analizi Sonuçları}

\begin{tabular}{|c|c|c|c|c|c|c|}
\hline \multirow{2}{*}{ Bağımlı Değişsen } & \multirow{2}{*}{ Bağımsız Değişken } & \multicolumn{2}{|c|}{ Standartlaştırılmamış Katsayı } & \multirow{2}{*}{$\begin{array}{c}\text { Standartlaştırılmış Katsayı } \\
\beta\end{array}$} & \multirow[b]{2}{*}{$t$} & \multirow[b]{2}{*}{$p$} \\
\hline & & A & $\varepsilon_{S_{h}}$ & & & \\
\hline \multirow{2}{*}{ İnovasyon } & (Sabit) & 0,338 & 0,220 & & 1,532 & 0,127 \\
\hline & Yetenek Yönetimi & 0,873 & 0,055 & 0,736 & 15,971 & 0,000 \\
\hline
\end{tabular}

Yetenek yönetimi inovasyonun \%53,9’unu açıklamaktadır. Bağımsız değişkenin bağımlı değişken üzerindeki etkisini gösteren model, ANOVA testi sonuçlarına göre anlamlıdır $(\mathrm{p}=0,000 \leq 0,01)$. Yukarıdaki tabloya göre sabitdeğer anlamlı değilken, bağımsız değişkenin katsayısı anlamlı olduğu görülmektedir $(p=0,000 \leq 0,01)$. Yetenek yönetimi değişkenine ait regresyon yükü 0,873 ve standartlaştırılmış regresyon yükü de 0,736'dır. Yetenek yönetimi çalışanlardaki inovasyon algısını 0,873 puan yükseltmektedir. Yetenek yönetimi değişkeni inovasyon değişkenini anlamlı bir şekilde yordamaktadir.

Basit doğrusal regresyon modeli: İnovasyon=0,736*Yetenek Yönetimi

Çizelge 12. Çoklu Doğrusal Regresyon Analizi Sonuçları

\begin{tabular}{|c|c|c|c|c|c|c|}
\hline \multirow{2}{*}{ Bağımlı Değişken } & \multirow{2}{*}{ Bağımsız Değişken } & \multicolumn{2}{|c|}{ Standartlaştırılmamış Katsayı } & \multirow{2}{*}{$\begin{array}{c}\text { Standartlaştırılmış Katsayı } \\
\beta\end{array}$} & \multirow{2}{*}{$t$} & \multirow{2}{*}{$p$} \\
\hline & & $B$ & $\varepsilon_{S_{h}}$ & & & \\
\hline \multirow{6}{*}{ İnovasyon } & (Sabit) & 0,559 & 0,328 & & 1,707 & 0,089 \\
\hline & Kurum Desteği Operasyonel Uyum & 0,331 & 0,034 & 0,520 & 9,753 & 0,000 \\
\hline & Kuruma Güven & 0,164 & 0,049 & 0,190 & 3,321 & 0,001 \\
\hline & İş Tatmini & 0,161 & 0,076 & 0,107 & 2,105 & 0,036 \\
\hline & Öz Yeterlilik Algısı & $-0,032$ & 0,055 & $-0,031$ & $-0,576$ & 0,565 \\
\hline & Yetkinlik & 0,211 & 0,055 & 0,209 & 3,852 & 0,000 \\
\hline
\end{tabular}

Kurum desteği ve operasyonel uyum, kuruma güven, iş tatmini ve yetkinlik değişkenleri birlikte inovasyonun \%57,2'sini açıklamaktadır. Bağımsız değişkenin bağımlı değişken üzerindeki etkisini gösteren model, ANOVA testi sonuçlarına göre anlamlıdır ( $\mathrm{p}=0,000 \leq 0,01)$. Yukarıdaki tabloya göre sabit değer anlamlı değilken, bağımsız değişkenlerden kurum desteği ve operasyonel uyum $(\mathrm{p}=0,000 \leq 0,01)$, kuruma güven $(\mathrm{p}=0,001 \leq 0,01)$, iş tatmini $(\mathrm{p}=0,036 \leq 0,05)$ ve yetkinlik $(\mathrm{p}=0,000 \leq 0,01)$ değişkenlerinin katsayılarının anlamlı olduğu görülmektedir. Kurum desteği ve operasyonel uyum değiş̧kenine ait regresyon yükü 0,331 ve standartlaştırılmış regresyon yükü de 0,520; kuruma güven değişkenine ait regresyon yükü 0,164 ve standartlaştırılmış regresyon yükü de 0,190 ; iş tatmini değişkenine ait regresyon yükü 0,161 ve standartlaştırılmış regresyon yükü de 0,107 ; yetkinlik değişkenine ait regresyon yükü 0,211 ve standartlaştırılmış regresyon yükü de 0,209 'dur. 
Kurum desteği ve operasyonel uyum çalışanlardaki inovasyon algısını 0,331, kuruma güven çalışanlardaki inovasyon algısını 0,164 , iş tatmini çalışanlardaki inovasyon algısını 0,161 ve yetkinlik çalışanlardaki inovasyon algısını 0,211 puan yükseltmektedir. Kurum desteği ve operasyonel uyum, kuruma güven, iş tatmini ve yetkinlik değişkenleri birlikte inovasyon değişkenini anlamlı bir şekilde yordamaktadir.

Çoklu doğrusal regresyon modeli: İnovasyon $=0,520 *$ Kurum Desteği ve Operasyonel Uyum + $0,190 *$ Kuruma Güven $+0,107 *$ İs Tatmini $+0,209 *$ Yetkinlik

\section{SONUÇ VE ÖNERILER}

Bu çalışmada insan kaynakları yönetiminde yeni bir yaklaşım olarak karşımıza çıkan yetenek yönetimi kavramının, işletmelerde inovasyon üzerine etkisi ele alınmıştır. Saha çalışmasında yapılan ölçümler tutarlılık analizi ile değerlendirilmiştir. Bu analizden hareketle, yetenek yönetiminin anket evreninde kavramsal olarak iyi bilindiği, inovasyonun yeni gelişen bir süreç olarak algılandığı gözlenmiştir. Araştırmanın sonuçlarına göre yetenek yönetiminin alt boyutları olan kurum desteği ve operasyonel uyum, kuruma güven, iş tatmini ve yetkinlik değişskenleri birlikte inovasyon değişkenini açıklamaktadır.

Araştırma kapsamında, anket yapılan endüstriyel mutfak firmasının yetenek yönetiminin etkin bir şekilde uygulandığı ancak inovasyon çalışmalarındaki süreçlerde geliştirilebilir bir seviyede olduğu görülmektedir. Çalışmada, araştırmacıların kendi çalışmalarında yararlanmaları açısından örnek bir model oluşturulmuştur. Demografik veriler cinsiyet, yaş, eğitim ve deneyime dayalı bilgilerin yanı sıra yetenek yönetimi uygulamaları ve inovasyon performansı ile ilgili sorular sorulmuştur. Bu makaledeki araştırma yapısı, örneklenen sektörün özelliklerine ve yetenek yönetimi ve yenilik performans sonuçları uygulamalarına hitap eden literatüre uygun olarak oluşturulmuştur. Alt kademedeki yönetici yetkinliğinin orta ve üst kademedeki yöneticilere göre daha yüksek olduğu, 7 yıl ve üzeri çalışanların yetenek yönetiminin 1-3 arasındakilere göre daha yüksek olduğu ve yine, 7 yıl ve üzeri çalışanların inovasyon algılarının 4-6 yıl arası çalışanlara göre daha yüksek olduğu belirlenmiştir.

Sonuç olarak, toplam iş tecrübesi arttıkça çalışanların yönetici yetkinliği ve inovasyon algısı daha da güçlenmektedir. Kurumsal verimlilik açısından ise, rekabet şartlarının yoğun seyrettiği sektörde inovasyonun itici bir unsur olarak firmayı geliştirebilmesi için inovasyonun destekleyici anahtarlarından biri olan yetenek yönetiminin başarılı bir şekilde kurgulanması ve başarılı inovatif çıktılar için başarılı bir yetenek yönetiminin gerekliliğinin ortaya çıktığı düşünülmektedir.

Yetenek yönetimi sistematik alt süreçleriyle birlikte kapsamlı bir süreç olduğu için firmaların, bu süreci başarılı yürütebilmesi için kurum içinde ilk önce yetenek yönetimi anlayışını içselleştirilmeleri 
gerekmektedir. Yönetici ve çalışanlar boyutunda bu sürecin benimsenmemesi durumunda verimde başarısızlık görülmeye başlar. İşte bu noktada firmalar üstün yetenekli çalışanları seçmeli, çalışanlara eğitim ve geliştirme alanları sağlanmalı, yetenekli çalışanlara koçluk yapmalı, yetenekli çalışanları değerlendirmek ve bu çalışanları elde tutmak bilinciyle hareket etmelidir. Yetenekli çalışanların elde tutulmasına ilişkin olarak çalışanlar özendirilmeli, motivasyon araçları kullanılmalı, yetenekli çalışanlara kapsamlı destekler sağlanmalı, uygun çalışma koşulları oluşturulmalı ve kişiye uygun işler sağlanmalıdır. Bu sayede firmalar yetenek yönetimini doğru uygulayıp inovasyon süreçlerini hızlı ve kaliteli bir şekilde yürütebileceklerdir.

Yetenek değişkeninin alt boyutları kurum desteği ve operasyonel uyum, kuruma güven, iş tatmini ve yetkinliğin inovasyon değişkenini anlamlı bir şekilde etkilediğinden hareketle, başarılı bir inovasyonun yürütülmesinde yeteneğin çok önemli bir faktör olduğu ifade edilebilir. Buna dayanarak gerek kamu gerekse özel sektörde işe alım ve iş yapış süreçlerinde yetenek faktörünün kurum başarısına etkisinden hareketle, bu faktörün önemle dikkate alınması önerilmektedir. Bu çalışmanın kısıtı araştırmanın belli bir sektörde ve belli bir sayıda katılımcı ile yapılabilmesidir. Saha araştırmasının, daha fazla sektörde ve daha çok sayıda veri ile ve/ya bölgesel veya küresel çapta yapılması hem literatüre hem de sektörel çalıșma alanlarına katkı sağlayacaktır. Hatta araştırmaların üretim ve hizmet sektörü veya bölgesel tabanlı mukayeseli çalışmalara dönüştürülmesi ve yaygınlaştırılmasının işletmelerin başarılarına katkı sağlaması bakımından faydalı olacağı düşünülmektedir. Ayrıca günümüzde dijitalleşmenin işletme performansları açısından çok önemli hale gelmesi ve dijitalleşme eğilimli inovasyon tabanlı çalışmaları daha güçlü rekabet unsuru haline dönüştürmesinin, inovatif süreçleri geliştirecek yetenek faktörünün önemini daha da artıracağ 1 öngörülmektedir. 


\section{KAYNAKLAR}

Ağraş, S. ve Kılınç İ. (2014). "Örgütsel Yeteneklerin Türkiye'deki Otel İşletmeleri Bağlamında Analizi", Manas Sosyal Araştırmalar Dergisi, 3(4), s. 1-35.

Akar, F. (2015). Yetenek Yönetimi. Ankara, İmge Kitabevi Yayınları 17-20.

Altınöz, M. (2018). "Yetenek Yönetiminin Algılanması Üzerine Karşılaştırmalı Bir Araştırma”, Selçuk Üniversitesi Sosyal Bilimler Enstitüsü Dergisi, 39, s. 85-95.

Arshi, T. (2013). "Can Organizational Culture Influence Innovation? An Empirical Study on Organizational Culture Characteristics and Innovative Intensity", Scottish Journal of Arts, Social Sciences and Scientific Studies, 10 (2), p. 3-17.

Buckingham, M. ve Vosburgh, R. M. (2001). “The 21st century human resourcesfunction: It's the talent, stupid!", Human Resource Planning, 24 (4), p.17-23.

Budak, G. ve Akyol Mayatürk, E. (2013). "Yetkinliğe Dayalı İnsan Kaynakları Yönetimi: Çok Uluslu Bir Firma Örneği”, Afyon Kocatepe Üniversitesi İktisadi ve İdari Bilimler Fakültesi Dergisi, s. 150-160.

Büyüköztürk, Ş. Kılıç, Çakmak, E. Akgün, Ö. E., Kardeniz, Ş. ve Demirel, F. (2018). Eğitimde Bilimsel Araştırma Yöntemleri, Ankara: PEGEM Yayınevi.

Claus, L. (2019). "HR Disruption Time Already to Reinvent Talentmanagement", Business Research Quarterly, p. 207-2015.

Collings, D.G. ve Mellahi, K. (2009). "Strategic Talent Management: A Review and Research Agenda”, Human Resource Management Review, 19(4), p. 304-313.

Damanpour, F. (1991). "Organizational Innovation: A Meta Analysis of Effects of Determinants and Moderators", Academy Of Management Journal, Vol.34, No.3, p. 555-590.

Drucker, P. F. (2003). Yenilikçilik İçerisinde Yenilikçilik Disiplini, (Çev Kardam, A.) İstanbul: MESS Yayınları.

Ecevit, S. Z. (2010). "Yenilik Yönetimi” (Ed. Odman, F. ve Çelikçapa Kaygusuz, S.) içinde "Teknoloji Yönetimi” Bursa: Dora Yayıncılık., s.119.

Elçi, Ş. (2006). İnovasyon Kalkınmanın ve Rekabetin Anahtarı, Ankara: Nova Basım, Yayın Dağıtım

Ertuğ, K. Z. ve Bülbül, M. E. (2015). “İnovasyon Performansı Değerlendirme Sürecinde AHS ve GİA Bütünleşik Yaklaşımı: Süt Ürünleri Sektöründe Bir Uygulama", Dumlupınar Üniversitesi Sosyal Bilimler Dergisi, 43, s. 149-160.

Fagerberg, J. (2003). İnnovation A Guide to Literature, Center for Technology İnnovationand Culture, Oslo October 
Foteini, K. ve Johnston, K. (2020). "Talent Management: A Critical Literature Review and Research Agenda for Public Sector Human Resource Management", Public Management Review, 22(1), p.75-95.

Gunday, G., Ulusoy, G., Kilic, K. ve Alpkan, L. (2011). "Effects of Innovation Types on Firm Performance". International Journal of Production Economics, 133(2), p. 662676.

Gündüzalp, S. ve Boydak, Ö. (2019). “Akademisyenlerin Yetenek Yönetimi Algısı”, Gazi Eğitim Bilimleri Dergisi, 5(2), s. 1-14.

Güner, M. B. (2016). “Çalışanların Yetenek Yönetimi Algısının İş Motivasyonuna Etkisi”, (Yüksek Lisans Tezi), Doğuş Üniversitesi SBE.

Hamel, G. ve Prahalad, C. K. (1990). “The Core Competence of the Corporation", Harvard Business Review, 3, p. 79-92.

Hancıoğlu Y, Yeşilaydın G, (2016) ,"Stratejik Yönetimde Yeni Bir Rekabet Yaklaşımı" : Stratejik İnovasyon, Uluslararası Yönetim İktisat ve İşletme Dergisi, Cilt 12, Say1 29, 2016: s: 120,121

İrge, N. Tülin, (2016). "Yöneticiye Güvenin Çalışanın Motivasyona Etkisinde Lider Üye Etkileşiminin Rolü: Farklı Analiz Teknikleri ile Uygulamalı Örneği”. IIB International Refereed Academic Social Sciences Journals. s. 54-76

Kalaycı, Ş. (2008). SPSS Uygulamalı Çok Değişkenli İstatistik Teknikleri. Ankara, Asil Yayın Dağıtım Ltd. Şti.

Kanap Güngör, M. (2013). "Bilgi Çağında İnsan Kaynakları Yönetimine Bakış: İşletmelerde Yetenek Yönetimi ve Çalışan Performansına Etkisi Üzerine Bir Araştırma", (Yüksek Lisans Tezi), Haliç Üniversitesi SBE.

Klingebiel, R. ve Rammer, C. (2014). "Resource Allocation Strategy for Innovation Portfolio Management”, Strategic Management Journal, 35(2), p. 246-268.

Karabetyan, L. (2019). Örgütsel Öğrenme, Bilgi Yönetimi ve İnovasyonun Örgütsel Performansa Etkisi: Hizmet İşletmelerinde Bir Uygulama, Doktora Tezi, İstanbul Arel Üniversitesi Sosyal Bilimler Enstitüsü.

Erat, L., (2019). Yetenek yönetimi uygulamalarının çalışanların kariyer planlaması üzerindeki etkisi: Konya ilindeki 4 ve 5 ylldızlı konaklama işletmelerinde bir araştırma, Y.Lisans Tezi, Selçuk Üniversitesi, Sosyal Bilimler Enstitüsü.

Mahdiyeh, M., Atashsokhan, S., Khalilzadeh, M., Aghajanloo, A. ve Zohrehvandi, S. (2018). "Linking Project Success" and "Strategic Talent Management", Department of Industrial Engineering, Science and Research,764-774.

Mische, A. M. (2001). Strategic Renewal Becoming a High Performance Organization, 129(2). 
Öner, E. (2014). "Bankacılık Sektöründe Yetenek Yönetimi ve İlişkilendirildiği İnsan Kaynakları Fonksiyonları: Bir Uygulama", (Yüksek Lisans Tezi), Bahçeşehir Üniversitesi SBE.

Özdevecioğlu, M. ve Biçkes, D. M. (2012). “Örgütsel Öğrenme ve İnovasyon İlişkisi: Büyük Ölçekli İşletmelerde Bir Araştırma”, Erciyes Üniversitesi İktisadi ve İdari Bilimler Fakültesi Dergisi, 39, s. 19-45.

Rogers, E.M. (1995). Diffusion of İnnovations. The Free Press. New York.

Salau, O., Osibanjo, A., Adeniji, A., Oludayo, O., Falola, H., Igbinoba, E. ve Ogueyungbo, O. (2018). "Data Regarding Talent Management Practices and İnnovation Performance of Academic Staff in Atechnology-Driven Private University", Covenant University, Nigeriaarticle, 18 April 2018

Sattler, M. (2011). Excellence in Innovation Management: A Meta-AnalyticReview on the Predictors of Innovation Performance. SpringerScience \& Business Media, s.12

Savaşçı, İ. , Kazançoğlu, Y. (2004), Firmaların Yenilik Yaratma Sürecinde Serbest Bölgelerin Rölü, İIBF ( www.ogu.edu.tr/kongre bildirileri) s. 517

Tokmak, İ. (2008). "Stratejik İnsan Kaynakları Yönetiminin İşletmelerin Yenilikçilik Yeteneğine Etkisi ve Elektronik Sanayisine Yönelik Bir Araştırma", (Doktora Tezi), Sakarya Üniversitesi SBE.

Vatan, A. (2010). “Turizm İşletmelerinde İnovasyon: İstanbul'daki 5 Yıldızlı Konaklama İşletmelerinde Bir Araştırma”, (Yüksek Lisans Tezi), Balıkesir Üniversitesi SBE.

Yam, R. C., Lo, W., Tang, E. P. ve Lau, A. K. (2011). “Analysis of Sources of Innovation, Technological Innovation Capabilities, and Performance: An Empirical Study of Hong Kong Manufacturing Industries”, Research Policy ,40(3), p.391-402

Trott, P. (1998). Innovation Management and New Product Development. Prentice Hall, London.

TDK. http://www.tdkterim.gov.tr., Erişim : 09.09.2020.

İnovasyon Nedir?, www.inovation.net., Erişim: 09.09.2020 